\title{
HORIZONTAL EFFECT OF FUNDAMENTAL FREEDOMS AND THE RIGHT TO EQUALITY AFTER VIKING AND MANGOLD, AND THE IMPLICATIONS FOR COMMUNITY COMPETENCE
}

\begin{abstract}
Derrick Wyatt*
Summary: The judgments in Viking and Laval confirm the Court's previous case law on the horizontal effect of Articles 39, 43 and 49 EC, and extend the horizontal effect of Articles 43 and $49 \mathrm{EC}$ to cover collective action of trade unions by way of strikes, boycotts and the like. A significant knock-on effect is an extension of Community regulatory competence to cover this same subject matter, despite the contrary indications in Article 137(5) EC. The judgment in Viking implies that Article $28 \mathrm{EC}$ is also capable of horizontal effect, at least in cases where collective action of individuals produces regulatory effects similar to those resulting from State action. The Court's reasoning leaves room for future incremental increases in the horizontal effect of fundamental freedoms in cases which involve contractual rules, in particular rules regulating employed or self employed activities. The approach to horizontal effect in Viking supports, for example, the argument that provisions of a corporate constitution could amount to a restriction on freedom of establishment, as could action taken by the board of a company to frustrate a takeover bid. Advocate General Maduro in Viking argues that the Treaty rules on freedom of movement apply directly to any private action that is capable of effectively restricting others from exercising their right of freedom of movement. The present writer suggests further considerations as being relevant to determining the extent of the horizontal reach of fundamental freedoms. Normal market behaviour on the part of one market operator should not in principle be held to amount to a restriction on the fundamental freedom of another. But discriminatory conduct by market operators, or other conduct which falls outside the range of normal market behaviour, would seem capable of falling within the horizontal effect of a fundamental freedom, at any rate where it restricts access of other market operators, or consumers, to the market, or places market operators or consumers at a disadvantage because they have exercised a fundamental freedom. Account must be taken of the aims and wording of the freedom in question, along with the policy questions of whether it
\end{abstract}

\footnotetext{
* Professor Derrick Wyatt QC, St Edmund Hall, Oxford. I am grateful to Professor Stephen Weatherill, of the University of Oxford, for drawing to my attention the Telefonica 02 reference, and Regulation (EC) No 2560/2001 on charges for cross-border payments in euro.
} 
would be excessively burdensome to make private operators subject to the obligation to comply with the fundamental freedom in question, and whether any consequential extension of Community regulatory competence would unreasonably limit that of the Member States. A related issue to be taken into account is the possible horizontal effect of the fundamental principle of equality, as articulated in the Mangold case. Even a restrained reading of this much criticised case would suggest that the prohibition of discrimination on grounds of nationality in Article 12 EC might have horizontal effect in circumstances falling within the scope of Community law, such as the supply of goods, services, business accommodation and housing. A similar conclusion could be reached as regards discrimination in the sale of goods, services and real property to non residents. It would not be excessively burdensome to impose on private market operators the obligation not to depart from their normal terms and conditions of sale in the case of non-nationals or non-residents, unless such departure represented normal market behaviour. A possible example of discriminatory service provision contrary to the general principle of equality is that of excessive 'roaming' charges, which have been recently regulated by Regulation (EC) No 717/2007. A key question which arises in this context is the extent to which a market operator can, or should be able to be, justify discrimination against out of state operators, or discrimination against customers solely because they have crossed a national frontier, on grounds of normal market behaviour, when market conditions are not normal, and the market is not fully competitive.

\section{Viking}

\section{The factual framework}

Advocate General Maduro described the situation that gave rise to the Viking case' 'in a nutshell' as follows:

A Finnish operator of ferry services between Helsinki and Tallin wished to change its place of establishment to Estonia in order to benefit from lower wage levels and provide its services from there. A Finnish trade union, supported by an international association of trade unions, sought to prevent this from happening and threatened strike action and boycotts if the company were to move without maintaining its current wage levels. The legal problems raised by this stand-off touch on the horizontal effect of the Treaty provisions

\footnotetext{
${ }^{1}$ Case C-438/05 International Transport Workers' Federation, Finnish Seamen's Union v Viking Line ABP, OÜ Viking Line Eesti, Judgment of 11 December 2007 (hereafter Viking).
} 
on freedom of movement, and on the relationship between social rights and the rights to freedom of movement. ${ }^{2}$

Viking, a Finnish company, operated the Rosella, which, under the Finnish flag, sailed the route between Tallinn (Estonia) and Helsinki (Finland). So long as the Rosella was under the Finnish flag, Viking was obliged to under Finnish law and the terms of a collective bargaining agreement to pay the crew wages at the same level as those applicable in Finland. The Rosella was running at a loss as a result from competition from Estonian vessels operating on the same route with lower wage costs. As an alternative to selling the vessel, Viking sought to re-flag it by registering it in Estonia.

The Finnish Seamen's Union (FSU) refused to agree to a renewal of the current manning agreement unless two conditions were satisfied. The first was that, even after re-flagging, Viking undertook to continue to follow Finnish law, and to follow relevant collective agreements relating to the Rosella. The second was that the change of flag would not lead to changes in the terms and conditions of employment of employees without their consent, and that it would not lead to any laying-off of employees in any Finnish flag vessel belonging to Viking. The FSU undertook strike action in support of its position.

According to the referring court, FSU was fully aware of the fact that its principal demand, that in the event of re-flagging the crew would continue to be employed on the conditions laid down by Finnish law and the applicable collective agreement, would render re-flagging pointless, since the whole purpose of such reflagging was to enable Viking to reduce its wage costs.

The International Transport Workers' Federation (ITF) pursued a policy called the 'Flag of Convenience' (FOC) policy. The ITF considered that a vessel sailed under a flag of convenience where the beneficial ownership and control of the vessel was found to lie in a State other than the State of the flag. The ITF considered that only unions established in the State of beneficial ownership of a vessel had the right to conclude collective agreements covering the vessel concerned. The FOC policy was enforced by boycotts and other solidarity actions amongst workers. The ITF sent a circular to affiliated unions asking them to refrain from entering into negotiations with Viking.

\section{The course of the legal proceedings}

Viking brought an action before the High Court in London ${ }^{3}$ requesting it to declare that the action taken by ITF and FSU was contrary to

\footnotetext{
2 Viking, Advocate General's Opinion para 1.

3 The secretariat of the ITF is located in London.
} 
Article $43 \mathrm{EC}$, to order the withdrawal of the ITF circular, and to order FSU not to infringe the rights which Viking enjoys under Community law. That Court granted the form of order sought by Viking, on the grounds that the actual and threatened collective action by the ITF and FSU imposed restrictions on the freedom of establishment, contrary to Article 43 $\mathrm{EC}$ and, in the alternative, constituted unlawful restrictions on freedom of movement for workers and freedom to provide services under Articles 39 and 49 EC.

ITF and FSU appealed against that decision to the referring court, the Court of Appeal (England and Wales) (Civil Division). The latter court referred a number of questions to the Court of Justice under Article 234 $\mathrm{EC}$, concerning the scope of relevant free movement provisions, their horizontal effect, the existence of restrictions on free movement, and possible justifications for any such restrictions.

\section{Summary of the judgment of the Court of Justice}

The Court held that a private undertaking could rely on Article 43 EC against private bodies such as FSU and ITF, where they took collective action which restricted the right of establishment of the undertaking concerned. The Court also held that that bodies such as FSU and ITF could justify such collective action on grounds of overriding reasons of public interest, in particular the protection of workers, providing that the jobs or conditions of employment at issue were jeopardised or under serious threat, and providing that the collective action in issue was suitable for achievement of the objective pursued and did not go beyond what was necessary to attain that objective.

\section{The scope of the present article}

The present article is concerned with the horizontal effect of the Treaty provisions on freedom of movement, and with consequential implications for Community competence, rather than on the relationship between social rights and the rights to freedom of movement. The Court's judgment in Viking provokes reflection on the legal principles underpinning the Court's conclusions as regards such horizontal effect. The Laval judgment ${ }^{4}$ is of significance in this respect only to the extent that it confirms in similar terms and on the same basis the horizontal direct effect of Article 49 EC. For the purposes of the present article, consideration can be largely confined to the Viking judgment. The Court's judgment in Mangold, upholding as it does the horizontal effect of the general prin-

\footnotetext{
${ }_{4}$ Case C-341/05 Laval un Partneri Ltd $v$ Svenska Byggnadsarbetareförbundet and others, judgment of 18 December 2007 (hereafter Laval).
} 
ciple of equality, is relevant in this context since it may reinforce and extend the horizontal effects of the fundamental freedoms. ${ }^{5}$ It may also to a corresponding extent increase Community regulatory competence. It will be recalled that in Mangold the Court of Justice held inter alia that the general principle of equality (in casu non discrimination on grounds of age) was capable of having horizontal effect within the scope of Community law.

\section{The Court's analysis in Viking of the legal basis for the horizontal effect of Article 43 EC $^{6}$}

The Court in Viking holds that Article 43 EC is capable of conferring rights on a private undertaking which may be relied upon against a trade union or an association of trade unions. The reasons for this conclusion are based on propositions drawn from the Court's previous case law.

The first proposition relied upon by the Court is that the abolition of obstacles to freedom of movement and freedom to provide services would be compromised if the abolition of State barriers could be neutralised by obstacles resulting from the exercise, by associations or organisations not governed by public law, of their legal autonomy. ${ }^{7}$ The present writer would note that this proposition is as much a policy consideration as a legal argument. In the cases cited by the Court, it is a proposition which has generally been cited in conjunction with other considerations, such as the fact that Articles $39 \mathrm{EC}$ and $49 \mathrm{EC}$ do not draw any distinction as to the source of the restrictions on free movement which are to abolished or prohibited. ${ }^{8}$ A further consideration cited in this context, and in the case law cited by the Court in Viking, is that working conditions in the different Member States are sometimes governed by law or regulation, and sometimes by agreements and other acts adopted by private persons; if the scope of Articles $39 \mathrm{EC}$ and $49 \mathrm{EC}$ were confined to acts of a public authority there would be a risk of creating inequality in its application. ${ }^{9}$ This consideration too is a policy consideration, but it is one which hints that the fact that Articles $39 \mathrm{EC}$ and $49 \mathrm{EC}$ do not draw any distinction

\footnotetext{
5 Case C-144/04 Mangold [2005] ECR I-9981.

6 The Court in Laval draws a similar conclusion as regards the horizontal effect of art 49 EC.

7 Viking para 57, citing Case 36/74 Walrave and Koch [1974] ECR 1405 para 18; Case C-415/93 Bosman [1995] ECR I-4921 para 83; Case C-191/97 Deliège [2000] ECR I-2549 para 47; Case C-281/98 Angonese [2000] ECR I-4139 para 32; and Case C-309/99 Wouters and Others [2002] ECR I-1577 para 120.

8 Case C-281/98 Angonese [2000] ECR I-4139 para 30; Case 36/74 Walrave and Koch [1974] ECR 1405 para 20.

9 Case C-415/93 Bosman [1995] ECR I-4921 para 84; Case 36/74 Walrave and Koch [1974] ECR 1405 para 19.
} 
as to the source of the restrictions to which they refer, might reflect the intent of the draftsman to avoid such inequality.

Further propositions relied upon by the Court for the horizontal effect of Article 43 EC are based on the judgment of the Court in Defrenne $v$ Sabena. ${ }^{10}$ In the latter case the Court holds that the fact that certain provisions of the Treaty are formally addressed to the Member States, does not prevent rights from being conferred at the same time on any individual who has an interest in compliance with the obligations thus laid down. ${ }^{11}$ The Court adds that the prohibition on prejudicing a fundamental freedom laid down in a provision of the Treaty that is mandatory in nature, applies in particular to all agreements intended to regulate paid labour collectively. ${ }^{12}$ The Court concluded that such considerations 'must also apply to Article $43 \mathrm{EC}$ which lays down a fundamental freedom, ${ }^{13}$ and added that, in the present case, the collective action taken was aimed 'at the conclusion of a collective agreement, which is meant to regulate the work of Viking's employees collectively. ${ }^{14}$

The Court's selective citation from the reasoning in Defrenne $v$ Sabena is worthy of remark. In particular, the Court does not refer to the paragraphs in the Defrenne judgment which hold that the reference in Article 141 EC to 'Member States' ensuring and maintaining application of the principle of equal pay is a reference to the judicial authorities of Member States as well as their legislative authorities. ${ }^{15}$ That is an argument which is capable of being advanced in favour of the horizontal application of Treaty provisions, as Advocate General Maduro points out. ${ }^{16}$

A further proposition relied upon by the Court is that restrictions on the free movement of goods may result from action of individuals or groups of individuals rather than being caused by the State. ${ }^{17}$ This aspect of the Court's reasoning is something of a new departure, given the context. The Court refers to its judgments in Commission $v$ France, ${ }^{18}$ and Schmidberger. ${ }^{19}$ It will be recalled that the first case raised the question whether failure by the French authorities to prevent acts of physical obstruction, damage to property, and violence directed, inter alia, at vehi-

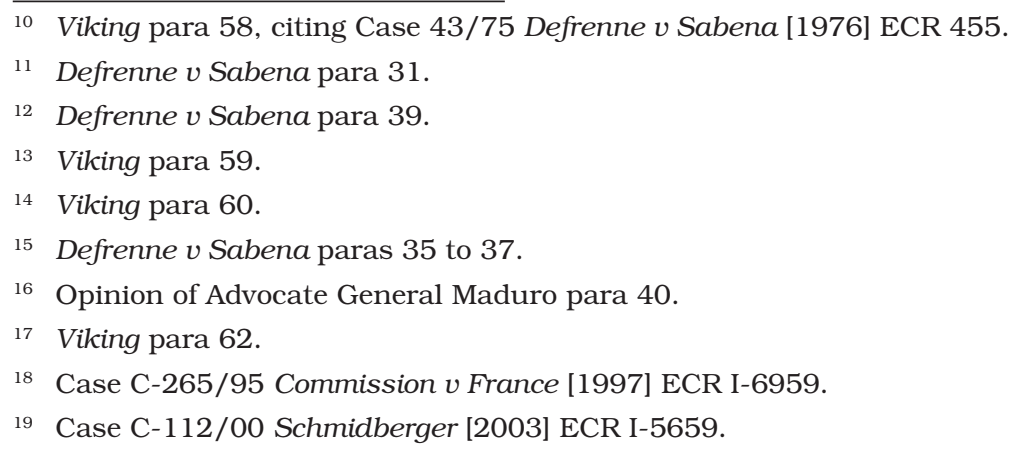


cles transporting imports into France, amounted to an infringement by France of Article $28 \mathrm{EC}$. The second case raised the question whether failure of the Austrian national authorities to prevent a demonstration leading to the complete closure of a major transit route for almost 30 hours amounted to an infringement of Article 28 EC by Austria. The Court cites paragraph 30 of its judgment in Commission $v$ France, which reads as follows:

As an indispensable instrument for the realization of a market without internal frontiers, Article [28] therefore does not prohibit solely measures emanating from the State which, in themselves, create restrictions on trade between Member States. It also applies where a Member State abstains from adopting the measures required in order to deal with obstacles to a free movement of goods which are not caused by the State. ${ }^{20}$

The Court in Viking also cites two paragraphs from its judgment in Schmidberger. The first simply repeats the gist of the above paragraph from the judgment in Commission $v$ France. The second paragraph reads:

It follows that, in a situation such as that in issue in the main proceedings, where the competent national authorities are faced with restrictions on the effective exercise of a fundamental freedom enshrined in the Treaty, such as the free movement of goods, which result from actions taken by individuals, they are required to take adequate steps to ensure that freedom in the Member State concerned even if, as in the main proceedings, those goods merely pass through Austria en route for Italy or Germany. ${ }^{21}$

These statements of the Court are clearly concerned with the duty of a Member State, pursuant to Article $28 \mathrm{EC}$, to take action to prevent individuals obstructing the transit of goods through a Member State. Yet in Viking the Court cites these statements as supporting the conclusion that Article 43 EC must be interpreted as meaning that it may in appropriate circumstances be relied upon by a private undertaking in a direct action against a trade union or an association of trade unions. ${ }^{22}$ Advocate General Maduro too thought that the significance of the above cases was not confined to actions against a Member State for inaction. ${ }^{23}$ He considered that '...constitutional rules that are addressed to the State translate into legal rules applying between private parties... ${ }^{24}$ In this context he referred to the ruling in Defrenne, in which the Court 'construed

\footnotetext{
Case C-265/95 Commission v France [1997] ECR I-6959 para 30.

${ }_{21}$ Case C-112/00 Schmidberger [2003] ECR I-5659 para 62.

22 Viking para 61.

23 Opinion paras 38 to 40 .

24 Opinion para 39.
} 
the horizontal effect of that provision as a duty on the national courts. ${ }^{25}$ There is no express indication in the Court's judgment that it endorses the broad proposition advanced by Advocate General Maduro, but the Court certainly considered that case law on the duty of Member States to prevent individuals from interfering with the free movement of goods was material to the question of the horizontal effect of Article $43 \mathrm{EC}$. The present writer agrees that such a link exists, but considers that it may be a more specific link with narrower implications than suggested by Advocate General Maduro.

It is significant that the Court rejects - fairly emphatically - the argument that horizontal direct effect can apply only 'to quasi-public organisations, or to associations exercising a regulatory task and having quasilegislative powers. ${ }^{26}$ The Court states that there is no indication in its case law that could validly support the view that it applies only to such organisations. ${ }^{27}$ Yet the Court adds that, 'in exercising their autonomous power...trade unions participate in the drawing up of agreements seeking to regulate paid work collectively.' The Court appears to be saying two things about 'regulation'. The second point about regulation is that trade unions participate in the collective regulation of paid work. This is presumably legally significant or the Court would not emphasise it. The present writer considers that it is legally significant, because regulatory action by the State is action subject to the fundamental freedoms, and if action is taken by private parties which can be regarded as analogous to State regulatory action, there is logic in treating such private action as similarly constrained by the fundamental freedoms. Yet the Court clearly does not wish to confine the regulatory action of private parties caught by the fundamental freedoms to regulatory action engaged in by regulators in a formal sense, such as international sporting associations, ${ }^{28}$ or professional bodies. ${ }^{29}$ This is consistent with the Court's reference to restrictions on the free movement of goods resulting from action by individuals or groups of individuals; in the cases in question the individuals or groups concerned temporarily regulated transit on the highway, though they clearly were not regulators in any formal sense. It is also consistent with recognising that, for example, the corporate constitution may be regarded as regulating the conditions of access to the market in shares of a company, for the purposes of the horizontal application of Article 43 EC. This point is addressed further below.

\footnotetext{
25 Opinion para 40.

26 Viking para 64, and the point is repeated in para 65.

27 Viking para 65.

28 See eg Case C-415/93 Bosman [1995] ECR I-492 1 para 87.

29 Case C-309/99 Wouters and Others [2002] ECR I-1577 para 120.
} 
Finally, the Court finds that collective action such as that in issue in Viking has the effect of making less attractive, or even pointless, Viking's exercise of the right to freedom of establishment. It followed that collective action such as that in issue in the national proceedings amounted to a restriction on freedom of establishment. ${ }^{30}$

It is appropriate to refer at this point to the link between the scope of fundamental freedoms, and the scope of Community regulatory competence, and to an argument rejected by the Court both in Viking and in Laval. The argument was to the effect that, since Article 137(5) EC exclude from the scope of Article 137 'pay, the right of association, the right to strike or the right to impose lock-outs', such matters were also excluded from the scope of Article $43 \mathrm{EC}$ and Article $49 \mathrm{EC}$. The Court rejected this argument on the basis that the fact that such matters remained in principle within national competence did not release Member States from the obligation to exercise that competence consistently with Community law. ${ }^{31}$ The argument that Article 137(5) EC militated against the application of Articles 43 and 49 EC to collective action perhaps received less attention than it deserved. The effect of holding that collective action including strike action falls within the scope of Article $43 \mathrm{EC}$ and Article $49 \mathrm{EC}$ would seem to have the consequence that such action also falls within the regulatory competence of the Community institutions pursuant to Article 47(2) EC (applicable to services by virtue of Article $55 \mathrm{EC}){ }^{32}$ It is a somewhat curious position that strike action is excluded entirely from the scope of Article 137, and that pursuant to that Article, Community measures concerning "collective defence of the interests of workers...' are subject to unanimity in Council, and to mere consultation with the European Parliament, ${ }^{33}$ while Community legislation based on Article 47(2) EC can apparently harmonise national rules covering both the collective defence of the interests of workers, and strike action, under the Article 251 procedure. ${ }^{34}$ An argument to the effect that Article 137(5) EC implies that strike action does not fall within the scope of Article 43 EC and Article 49 EC because if it did it would also fall also fall within the regulatory competence of the Community under Articles 47(2) EC and 55 EC, and thereby deprive Article 137(5) EC of much of its practical ef-

\footnotetext{
30 Viking para 72.

31 Viking para 40; Laval para 87. The argument was advanced by Denmark in Viking, and by Denmark and Sweden in Laval.

32 It seems that strike action and the collective defence of workers' interests concerns 'the pursuit of activities as self-employed persons' within the meaning of art 47(2) EC, since the Court in Viking and Laval holds that such action and collective defence of workers' interests is capable of restricting the right of establishment.

33 Art 137(2) EC.

34 Voting in Council would be by qualified majority.
} 
fect, is at the very least a plausible argument, and it not really addressed by the Court. Perhaps the argument was not put to the Court in those terms. But the link between the scope of fundamental freedoms and the scope of Community competence to regulate the internal market is a significant link. Extension of the horizontal scope of Treaty provisions in principle brings with it increased competence at the Community level to regulate private conduct, and that in turn narrows the area within which national authorities are free to regulate without the risk of being overruled at Community level.

\section{Advocate General Maduro's approach to horizontal direct effect in Viking}

The judgment in Viking provokes reflection on the legal principles underpinning the Court's conclusions on this point, and on the general scope of the horizontal effect of the fundamental freedoms. Advocate General Maduro analysed the extent to which Treaty provisions on freedom of movement create obligations for private actors. It is not possible in the span of this article to do full justice to his arguments, and what follows is a summary of his position. He thought that 'at the heart of the matter' lay the following question:

does the Treaty imply that, in order to ensure the proper functioning of the common market, the provisions on freedom of movement protect the rights of market participants, not just by limiting the powers of the authorities of the Member States, but also by limiting the autonomy of others? ${ }^{35}$

He answered this question in the affirmative. As noted above, he argued that the significance of Commission $v$ France and Schmidberger was not confined to actions against the State for inaction. He considered that constitutional rules addressed to the State translate into legal rules applying between private parties, and he cited in support of this approach the ruling in Defrenne, in which the Court treated the duty on Member States to ensure and maintain application of the principle of equal pay, as including a duty on national courts to bring this about.

Advocate General Maduro next asked: to what sort of private action do the rules of freedom of movement apply? He did not think that the rules on freedom of movement can always be brought into play in proceedings against a private individual. State authorities have considerably more potential to impede the proper functioning of the common market than private individuals. ${ }^{36}$ By way of contrast, in many circum-

35 Para 36 of his Opinion.

36 Para 41 of Opinion. 
stances private actors 'simply do not wield enough influence successfully to prevent others from enjoying their rights to freedom of movement.' He cites the example of an individual shopkeeper who refuses to purchase goods from other Member States as a case which would not be liable to obstruct the functioning of the common market. The reason given is that 'suppliers from other Member States would still have the opportunity to market their goods through alternative channels. ${ }^{37}$ Advocate General Maduro comes to the conclusion that the implication is that the rules on freedom of movement apply directly to any private action 'that is capable of effectively restricting others from exercising their right of freedom of movement. ${ }^{38}$ But he accepts that there is no simple answer to the question how to determine whether that is indeed the situation, and notes that the Court in its case law has proceeded carefully by recognising the direct horizontal application of the rules on freedom of movement in specific cases. He comes to the general conclusion that "the provisions on freedom of movement apply to private action that, by virtue of its general effect on the holders of rights of freedom of movement, is capable of restricting them from exercising those rights, by raising an obstacle that they cannot reasonably circumvent. ${ }^{39}$

\section{Further analysis - principle and policy considerations bearing on the scope of the horizontal effect of fundamental freedoms}

Advocate General Maduro's analysis is certainly plausible. Since it does not claim to be an exhaustive analysis it is appropriate to treat it as a starting point and explore other considerations of principle and policy which bear on the question of the horizontal scope of fundamental freedoms. The present write would suggest that the following general considerations are relevant to determining the extent of the horizontal reach of the fundamental freedoms.

In the first place, fundamental freedoms guarantee to market operators the right to carry on cross-border economic activities, and to compete with other market operators. It would seem to follow that normal market behaviour designed to improve the market position or market returns of one economic operator should not in principle be held to amount to a restriction on the fundamental freedom of another market operator.

Secondly, the concept of a restriction on a fundamental freedom implies action which is external to the market, or which at any rate falls outside the range of normal competitive market behaviour designed to increase market returns or improve the market position of operators vis-

\footnotetext{
37 Para 42 of Opinion.

38 Para 43 of Opinion.

39 Para 48 of Opinion.
} 
à-vis their competitors, or suppliers or customers. The archetypical example of a restriction on the exercise of a fundamental freedom is regulation of one sort or another of cross-border economic activity by public authorities of a Member State. The Court's case law to the effect that collective regulation of economic action by private operators acting under private law may amount to a restriction on a fundamental freedom is convincing. If private operators assume the mantle of market regulators, they will in turn be subject to those Treaty rules which fix limits on the regulation of cross-border economic activities.

Thirdly, discriminatory conduct by market operators, or other conduct which falls outside the range of normal competitive market behaviour, would seem capable of falling within the horizontal effect of a fundamental freedom, at any rate where it restricts access of other market operators, or consumers, to the market, or places market operators or consumers at a disadvantage because they have exercised a fundamental freedom. It should be emphasised however, that apparently discriminatory conduct may be justified on commercial grounds, and normal market behaviour should not be regarded as discrimination prohibited by the Treaty.

Whether particular conduct of this latter type amounts to a breach of a fundamental freedom will depend on the aims and wording of the freedom in question. In assessing the potential scope of the freedom in question, account must be taken of two further considerations. The first is the policy consideration of whether or not it would be excessively burdensome to make private market operators subject to the obligation to comply with the fundamental freedom in issue. The second is the impact upon Community legislative competence of extending application of a fundamental freedom to private market operators.

A related issue to be taken into account is the possible impact of the horizontal effect of the fundamental principle of equality, as articulated in the Mangold case. ${ }^{40}$ The general principle of equality includes the prohibition of discrimination on grounds of nationality laid down in Article $12 \mathrm{EC},{ }^{41}$ which provides that the latter prohibition applies within the scope of application of the Treaty, but without prejudice to any special provisions therein. The 'special provisions' referred to are in particular those other provisions of the Treaty in which the application of the general principle of non-discrimination on grounds of nationality is given concrete form in respect of specific situations, such as free movement of workers, the right of establishment and the freedom to provide services. ${ }^{42}$

40 Case C-144/04 Mangold [2005] ECR I-9981.

41 Case C-309/89 Codorniu [1994] ECR I-1853 para 26.

42 Case C-186/87 Cowan [1989] ECR 195 para 14. 
The effect of the proviso as regards such special provisions is that the general prohibition of discrimination on grounds of nationality 'applies independently only to situation governed by Community law in regard to which the Treaty lays down no specific prohibition of discrimination. ${ }^{24}$ Since the situations falling within the scope of Community law include those involving the exercise of fundamental freedoms, ${ }^{44}$ with the consequence that Article 12 EC may prohibit discrimination on grounds of nationality as regards a person exercising a fundamental freedom, yet the latter Article may only apply independently where the fundamental freedom does not itself prohibit discrimination on grounds of nationality in the situation in question, the effect of Article $12 \mathrm{EC}$ may be to reinforce, or supplement, the scope of fundamental freedoms in certain situations. The significance of this in the present context is that Mangold implies that Article $12 \mathrm{EC}$ is capable of horizontal application, since it comprises an aspect of the general principle of equality, which the Court in Mangold treats as being of horizontal application. The implications of the Mangold case are controversial, however, and it merits further consideration.

\section{The Mangold Case}

The Court of Justice appears in Mangold to have endorsed a proposition which is of significance to the present discussion: that the general principle of equality ( in casu the prohibition of age discrimination) is horizontally directly effective within the scope of Community law. The context for this ruling was the question whether a provision of Directive 2000/78 prohibiting inter alia discrimination on grounds of age in employment, could be applied in a dispute between an employee and his employer, to set aside a provision of national law inconsistent with the prohibition of discrimination on grounds of age, despite the fact that at the relevant time the period for implementation of the Directive in question had not expired. The Court noted that Directive 2000/78 did not itself lay down the principle of equal treatment in the field of employment and occupation, which was derived from international instruments and the constitutional traditions common to the Member States. It followed, in the Court's view, that non-discrimination on grounds of age must be regarded as a general principle of Community law, applicable to national rules falling within the scope of Community law, and capable of disapplying such rules if incompatible with the general principle in question.

The Mangold judgment has been criticised or qualified in the Opinions of a number of Advocates General, in various respects, and for vari-

\footnotetext{
43 Case 305/87 Commission v Greece [1989] ECR 1461 para 13.

44 C-184/99 Grzelczyk, [2001] ECR I-6193 para 33; Case C-148/02 Garcia Avello [2003] ECR I-11613 para 23.
} 
ous reasons. Advocate General Sharpston refers to a previous Opinion of her own, and to the Opinions of three other Advocates General, in Bartsch. ${ }^{45}$ In her Opinion in Bartsch, Advocate General Sharpston notes academic criticism of Mangold, as follows: ${ }^{46}$

Mangold has attracted a certain amount of academic criticism. The general theme of the criticism is that the Court (of its own volition, without good reason and against the wishes of the legislature) extended the scope of a directive, ${ }^{47}$ to give it effect before the end of its transitional period and in horizontal circumstances, by making an innovative reference to a general principle of Community law. ${ }^{48}$ Consequently, a number of commentators have expressed the opinion that the Court has undermined the purpose of direct effect. ${ }^{49}$ Furthermore, the ruling is criticised for having produced a situation of considerable legal uncertainty. ${ }^{50}$

In Carp, Advocate General Trstenjak argues that in Mangold the general principle of equality bestowed horizontal direct effect on Directive 2000/78, which prohibited discrimination based on age. ${ }^{51}$ In Othmar Michaeler Subito GmbH, Advocate General Ruiz-Jarabo Colomer argues for a minimalist reading, or re-reading, of Mangold, to the effect that:

\footnotetext{
45 See the Opinion of Advocate General Sharpston of 22 May 2008, in Case C-427/06 Birgit Bartsch paras 33-41, referring to (1)Advocate General Geelhoed in Case C-13/05 Chacón Navas [2006] ECR- I 6467, (2) herself, in Case C-227/04 P Lindorfer [2007] ECR I-6767. (3) Advocate General Mazák in Case C-411/05 Palacios de la Villa [2007] ECR I-8531, and (4) Advocate General Ruiz-Jarabo Colomer in Case C-267/06 Maruko, judgment of 1 April 2008, not yet reported.

46 Para 31 of her Opinion.

47 See, for example, J Cavallini, 'De la suppression des restrictions à la conclusion d'un contrat à durée déterminée lorsque le salarié est un senior' (2005) La Semaine Juridique Sociale 25-28; O Dubos, 'La Cour de justice, le renvoi préjudiciel, l'invocabilité des directives: de l'apostasie à l'hérésie?' (2006) La Semaine Juridique 1295-1297; O LeClerc, 'Le contrat de travail des seniors à l'épreuve du droit communautaire' (2006) Recueil Dalloz 557-561; M Nicolella, 'Une application anticipée des directives non transposées?' (2006) Gazette du Palais 22; E Dubout, 'Mangold' (2005) Revue des Affaires Européennes 723-733; A Masson and C Micheau, 'The Werner Mangold Case: An Example of Legal Militancy' (2007) European Public Law 587-593; Editorial Comments, CML Rev 2006, 1-8.

48 See, for example, K Riesenhuber, Case Note (2007) European Review of Contract Law 62; J Swift, 'Pale, stale, male' (2007) NLJ 532-534; Editorial Comments, CML Rev, cited above. This is viewed positively from a rights perspective in D Schiek, 'The ECJ Decision in Mangold: A Further Twist on Effects of Directives and Constitutional Relevance of Community Equality Legislation' (2006) ILJ 329-341.

49 See, for example, Cavallini, Dubos, 'Editorial Comments' CML Rev (n 47).

50 See, for example, Swift (n 48) Cavallini, Nicolella, Dubout, Masson/Micheau (n 47); D Martin, 'L'arrêt Mangold - Vers une hiérarchie inversée du droit à l'égalité en droit communautaire?'(2006) Journal des Tribunaux du Travail 109-116.

51 Case C-80/06 Carp [2007] ECR I - 4473, Opinion of Advocate General para 70.
} 
It would be preferable, where they are invoked in cases concerning directives, if the general principles of law acted as criteria for interpretation. In that way, the relationship between the principles and directives would create a climate more likely to guarantee legal certainty and more in keeping with the institutional equilibrium underlying a system of sources such as the Community one. ${ }^{52}$

Advocate General Sharpston addresses the question of the horizontal direct effect of the principle of equality in Bartsch, and considers that 'one should be slow to exclude the possibility that a general principle of Community law may, in appropriate circumstances, be applied horizontally.' 53

In light of the criticism levelled at Mangold, it would be unwise to accept at face value the proposition that the general principle of equality is horizontally directly effective in all its various manifestations, and to all situations falling within the scope of Community law. But it might nevertheless be appropriate to rely on Mangold to support the rather narrower proposition that the general principle of equality, and in particular the prohibition of discrimination on grounds of nationality laid down in Article $12 \mathrm{EC}$, is horizontally directly effective in those cases where such effect would reinforce and supplement the scope of fundamental freedoms, and be conducive to achieving the aims of the internal market. Walrave and Koch suggests that Article $12 \mathrm{EC}$ is capable in principle of horizontal application. ${ }^{54} \mathrm{~A}$ general argument in favour of the horizontal effect of Article $12 \mathrm{EC}$ is that it does not draw any distinction as to the source - public or private - of the discrimination which is to be prohibited. In the case of other Treaty Articles, such as Articles 39 EC and 49 EC, the Court has regarded it as a factor favouring the possibility of horizontal effect that these provisions do not draw any distinction as to the source of the restrictions on free movement which are to abolished or prohibited. ${ }^{55}$ The present writer considers that recognising the horizontal direct effect of Article 12 in certain situations involving the exercise of fundamental freedoms, in particular as regards discrimination on grounds of nationality in the supply of goods, services, business premises and housing, would reinforce fundamental freedoms and be conducive to achieving the aims of the internal market, without placing excessive burdens on private operators. The present writer would make the same point as regards

\footnotetext{
52 Joined Cases C-55/07 and C-56/07 Othmar Michaeler Subito GmbH Judgment of the Court of 24 April 2008, Opinion of the Advocate General para 22.

53 Opinion of Advocate General Sharpston of 22 May 2008, in Case C-427/06 Birgit Bartsch paras 79-85.

54 Case 36/74 Walrave and Koch [1974] ECR 1405 paras 16, 17 and 25.

55 Case C-281/98 Angonese [2000] ECR I - 4139 para 30; Case 36/74 Walrave and Koch [1974] ECR 1405 para 20.
} 
discrimination by private operators against non resident customers. It is to be noted that discrimination against non-residents may amount to indirect discrimination on grounds of nationality, and also comprises discrimination which falls within the scope of fundamental freedoms, viz., the freedom to provide services, and the free movement of goods. ${ }^{56}$ According horizontal effect to discrimination on grounds of residence would thus reinforce the effect of fundamental freedoms and be conducive to achieving the aims of the internal market. But in considering the scope of the duties of non discrimination referred to, account should still be taken of the general considerations referred to above, and in particular of the consideration that normal market behaviour should not be regarded as comprising discrimination prohibited by the Treaty.

\section{Reflections on the approach adopted in Viking to collective action by trade union bodies as a restriction on freedom of establishment}

The approach adopted by the Court in Viking to the question of the horizontal direct effect of Article $43 \mathrm{EC}$ is based on its previous case law. While the Court denies that the principle to be derived from the cases on 'collective regulation' is limited to cases of organisation exercising a regulatory task or having quasi-legislative powers, the Court notes that 'trade unions participate in the drawing up of agreements seeking to regulate paid work collectively. ${ }^{57}$ This is a plausible basis for holding that Article $43 \mathrm{EC}$ may apply to the terms of collective agreements, and to collective action by trade unions relating to terms and conditions of employment, for the reasons given above - in particular, if private operators assume the mantle of market regulators, they will be subject to those Treaty rules which fix limits on the regulation of cross-border economic activities. That being the case, since the collective action in question was found by the Court to restrict the right of establishment of Viking, it was necessary to consider the issues of justification, and the proportionality of the collective action in issue.

As regards justification, the Court held that that bodies such as FSU and ITF could justify such collective action on grounds of overriding reasons of public interest, in particular the protection of workers, providing that the jobs or conditions of employment at issue were jeopardised or under serious threat, and providing that the collective action in issue was suitable for achievement of the objective pursued and did not go beyond what was necessary to attain that objective. In this regard, the Court im-

\footnotetext{
56 It is noted below that the right of individuals to cross national frontiers for the purpose of shopping falls within the scope of the free movement of goods, see Case C-362/88 GBINNO-BM [1990] ECR I-667 para 8.

57 Viking para 65.
} 
plies that collective action could not be justified in order to prevent the progressive replacement of seamen covered by the original Finnish agreement by seamen employed under Estonian law, or under any subsequent agreement negotiated under Estonian law. ${ }^{58}$ Lawful collective action by the union would seem to be confined to protecting the terms and conditions of employment, and jobs of its members, and such action could not lawfully extend to regulating the terms and conditions of employment of future employees. ${ }^{59}$

It is argued above that the normal market behaviour of one market operator cannot in principle in itself amount to a restriction on the fundamental freedom of another market operator. Should this lead to the conclusion that collective action by trade unions in pursuit of the interests of their members is not in principle caught by Article $43 \mathrm{EC}$ since it simply amounts to negotiation by or on behalf of market operators (workers) to improve their market position? It might be objected that collective action is a cartelised means of improving the market position of workers, and that it involves resort to pressures external to the play of market forces, such as boycotts, which the ITF used in pursuance of their FOC policy. But for certain purposes at least, it seems that collective action by trade unions is to be regarded as normal market behaviour. Thus in Albany the Court of Justice held that certain restrictions of competition are inherent in collective agreements, but that the social policy objectives pursued by such agreements would be seriously undermined if management and labour were subject to Article 85(1) of the Treaty when seeking jointly to adopt measures to improve conditions of work and employment. ${ }^{60}$ In the Viking case, FSU and ITF argued that Albany should be applied by analogy to the case in the main proceedings, since certain restrictions on freedom of establishment and freedom to provide services were inherent in collective action taken in the context of collective negotiations. The Court rejected this argument, denying that it could be considered to be inherent in the very exercise of trade union rights and the right to take collective action that fundamental freedoms will be prejudiced to a certain degree. ${ }^{61}$

\footnotetext{
58 Viking paras 81 and 82.

59 This view seems to be shared by ACL Davies, 'One Step Forward, Two Steps Back? The Viking and Laval Cases in the ECJ' (2008) ILJ Oxford Legal Studies Research Paper No $12 / 2008$

60 Case 67/96 Albany International BV v Stichting Bedrijfspensioenfonds Textielindustrie [1999] ECR I-5751 para 59.

${ }^{61}$ Viking para 52. The Court also reasons that the fact that an agreement or activity is excluded from the scope of the provisions of the Treaty on competition does not mean that that agreement or activity also falls outside the scope of the Treaty provisions on free movement of persons or services, since those two sets of provisions are to be applied in different sets of circumstances (Viking para 53). The Court adds that it has already held that the
} 
This latter aspect of the Court's reasoning is not entirely convincing. It is surely inherent in the legal recognition of the right to take collective action that managerial decisions will be prejudiced to a certain degree, and it would be curious indeed if managerial decisions involving crossborder activity were wholly immune from such prejudice. But even if it is accepted that collective action should be treated as normal market behaviour for workers and those who represent their interests, and accordingly as not per se a restriction on the right of establishment of an employer, this argument could only be maintained to the extent that the collective action in question promotes and protects the working conditions of current members of the union concerned. To the extent that collective action seeks to determine such matters as, for example, the Member State in which a vessel is to be registered, or the terms and conditions applicable to future employees who are not its members and may never be its members, the action would seem to amount to regulation of the market, and at that point Article 43 EC should be applicable. On this view, admittedly, it would still in principle be possible to justify the collective action in question on grounds of overriding reasons of public interest, provided that the action were appropriate and proportionate. But in the case in point, the aim of the collective action was to render the re-flagging of the vessel in question pointless, and thereby to deprive Viking's exercise of the right of establishment of all practical effect. Even if the action of the FSU and ITF were regarded as falling within the scope of Article $43 \mathrm{EC}$ only at the point at which it went beyond furtherance of the interests of employees represented by those bodies, justification of the action in issue in terms of proportionality would seem to be problematic.

On the facts of Viking, both these arguments, that is to say, that accepted by the Court of Justice, and that advanced hypothetically by the present writer, would seem to lead to the same outcome, which is to the effect that collective action by the trade union bodies concerned are consistent with Community law to the extent that they are strictly related to maintaining the market position of their present members; if the collective action goes further than that, it amounts to regulation of the market contrary to Article $43 \mathrm{EC}$ which cannot be justified by the protection of the interests of trade union members.

terms of collective agreements are not excluded from the scope of the Treaty provisions on freedom of movement for persons (Viking para 54). 
The horizontal scope of Article 28 EC

\section{Article 28 EC applies to State measures and private action analogous to State action}

The text of Article $28 \mathrm{EC}^{62}$ suggests that its aim is to prohibit State measures which impose quantitative restrictions, or measures having equivalent effect, on trade between Member States. This inference is supported by the text of the formerly applicable standstill provision, which stated that 'Member States shall refrain from introducing between themselves any new quantitative restrictions or measures having equivalent effect' (Article $31 \mathrm{EC}$ prior to the Amsterdam amendments) (emphasis added). The Court has said that the concept of a quantitative restriction 'covers measures which amount to a partial or total restraint of, according to the circumstances, imports, exports or goods in transit. ${ }^{63}$ Measures having equivalent effect 'not only take the form of restraint described; whatever the description or technique employed, they can also consist of encumbrances having the same effect. ${ }^{64}$ In order for measures to amount to such 'restraints' or 'encumbrances' it would seem necessary for them to interpose themselves in some way between potential purchasers of imported goods and potential sellers of those goods.

In Commission $v$ France, ${ }^{65}$ and Schmidberger, ${ }^{66}$ the private action in issue had the aim and effect of preventing normal transit on the highway. The action thus interposed itself between potential purchasers and potential sellers of the goods in a manner analogous to regulatory action of the State. The private action in question displaced, however temporarily, the prerogatives of the state to regulate transit on the highway. The Court implies in Viking that such action is subject directly to the application of Article 28 EC. It may be that Article $28 \mathrm{EC}$ applies horizontally solely to that private action which seeks to regulate trade or the transit of goods, in a way analogous to the ways in which State authorities regulate trade or the transit of goods. The form of such regulation, however, need not in principle amount to physical interference with the transit of goods.

The effect of applying Article $28 \mathrm{EC}$ to private action restricting the free movement of goods is that such action in turn becomes, in principle, subject to the competence of the Community institutions to regulate the internal market, subject to restraints on such regulation resulting from

\footnotetext{
62 'Quantitative restrictions on imports and all measures having equivalent effect shall be prohibited between Member States.'

63 Case 2/73 Geddo $v$ Ente Nazionale Risi [1973] ECR 865 para 7.

64 Case 2/73 Geddo $v$ Ente Nazionale Risi [1973] ECR 865 para 7.

65 Case C-265/95 Commission v France [1997] ECR I-6959.

66 Case C-112/00 Schmidberger [2003] ECR I-5659.
} 
the general principles of law, including fundamental rights. One outcome of the judgment of the Court of Justice in Commission $v$ France was the adoption of Council Regulation (EC) No 2679/9 on the functioning of the internal market in relation to the free movement of goods among the Member States, based on Article 308 EC. ${ }^{67}$ The Regulation provides inter alia that where serious disruption to the free movement of goods occurs in a Member State, the Member State concerned shall take all necessary and proportionate measures so that the free movement of goods is assured in the territory of the Member State in accordance with the Treaty. ${ }^{68}$ The Regulation may not however be interpreted as affecting in any way the exercise of fundamental rights as recognised in Member States, including the right or freedom to strike, or exercise any other right or freedom bestowed by the specific industrial relations systems in Member States. ${ }^{69}$ It does not follow, however, that regulation of the right to strike and other collective action fall outside the scope of Community regulatory competence. In Viking and Laval, the Court balances the fundamental right to strike against the fundamental economic freedom to carry on business across national frontiers, and in so doing defines the limits of each right and freedom in the context in question. If the Court of Justice is competent to undertake this balancing exercise in the exercise of its judicial competence, then the Commission, Council and Parliament are in principle competent to undertake a similar exercise in the exercise of their legislative functions. In the context of the free movement of goods, the only available Treaty base for regulation of collective action of workers would seem to be Article $308 \mathrm{EC}$, since Article 95 (2) EC excludes from the scope of Article 95(1) EC provisions 'relating to the rights and interests of employed persons.'

\section{Article 28 EC is applicable to purchasing choices by State authorities}

There is no indication in Article $28 \mathrm{EC}$ that it aims to regulate purchasing choices. Indeed, in a consistent case law, the Court of Justice has described measures having equivalent effect to quantitative restrictions as all 'trading rules enacted by Member States which are capable of hindering, directly or indirectly, actually or potentially, intra-Community trade' (emphasis added). ${ }^{70}$ The Court has also described Article $28 \mathrm{EC}$ as

67 [1998] OJ L 337/8.

68 Art 4 and art 1.

69 Art 2.

70 Case 8/74 Dassonville [1974] ECR 836 paras 5-8. The Court continues to reiterate this formulation, see, for example, Case C-244/06 Dynamic Medien Vertriebs GmbH v Avides Media AG judgment of 14 February 2008 para 26. 
applying to the marketing of products. ${ }^{71}$ These formulations used by the Court in describing the measures covered by Article 28 do not suggest that purchasing choices which favour domestic products would amount to measures covered by Article $28 \mathrm{EC}$. It would seem to follow that if, e.g., individual consumers admit to making discriminatory choices by favouring domestic products, their conduct would not fall within the scope of Article 28 EC. Moreover, from a policy point of view it would be excessively intrusive and burdensome to hold purchasing decisions by private individuals to be subject to Article 28 EC.

On the other hand, it is established that Article 28 EC does apply to the purchasing choices of public authorities. ${ }^{72}$ It is also established that recommendations by or on behalf of the State to purchase products of local origin fall within the scope of Article 28. ${ }^{73}$ Advertising campaigns by producers encouraging consumers to buy their products constitute normal market behaviour designed to improve the position of those concerned on the market, and do not fall within the scope of Article $28 \mathrm{EC}^{74}$ The present writer considers that the same is true of advertising campaigns by producers encouraging consumers to buy goods of local rather than foreign origin.

Purchasing choices made by State authorities are intrinsically susceptible to being influenced by the policy consideration of giving preference to national products, and may for that reason be equated to measures which regulate trade in goods. The Court of Justice has indicated that the aim of Community rules on procurement by public bodies is to avoid the risk of preference being given to national tenderers and to avoid the possibility that public bodies may choose to be guided by considerations other than economic ones. ${ }^{75}$ If public bodies recommended

\footnotetext{
71 Joined Cases 3/76, 4/76 and 6/76 Kramer [1976] ECR 1279 para 55.

72 See Arrowsmith, The Law of Public and Utilities Procurement $\left(2^{\text {nd }}\right.$ edn Sweet and Maxwell 2005) 183-186.

73 Recommendations by public authorities encouraging preference for domestic products falls within the scope of art 2(3)(k) of Directive 70/50/EEC; see Case 249/81 Commission $v$ Ireland [1982] ECR 4005; Case 222/82 Apple and Pear Development Council [1983] ECR 4083.

74 In Case 249/81 Commission v Ireland [1982] ECR 4005, the Court refers to the "buy Irish' campaign sponsored by the Irish government and states, at para 23, that 'the first observation to be made is that the campaign cannot be likened to advertising by private or public undertakings, or by a group of undertakings, to encourage people to buy goods produced by those undertakings.... In Case 222/82 Apple and Pear Development Council [1983] ECR 4083, the Court states at para 17 that 'in fact, a body such as the Development Council, which is set up by the Government of a Member State and is financed by a charge imposed on growers, cannot under Community law enjoy the same freedom as regards the methods of advertising used as that enjoyed by producers themselves or producers' associations of a voluntary character.'

75 Case C-470/99 Universale-Bau AG [2002] ECR I-11617 para 52.
} 
or imposed such preferences on private market operators or consumers, such recommendations or requirements would amount to trading rules affecting the marketing of products. Where public bodies choose to be guided by considerations other than economic ones, such as national preference, the effect is as much regulation of the market as would be the imposition of such preferences on private market operators or consumers. In such circumstances what appears to be a purchasing choice in fact has a dual character. The purchasing choice is combined with a regulatory choice on the part of the State. It is the regulatory choice by the State which amounts to a measure having equivalent effect to a quantitative restriction within the meaning of Article 28 EC.

\section{Article 28 EC should not be regarded as applicable to purchasing choices by private market operators}

Individual purchasing choices by private operators cannot be equated with purchasing choices by public authorities. If a private market operator (such as a supermarket) chooses to discriminate against imports in order to favour local produce and local employment, that choice is not subject to the regulatory constraint characteristic of a quantitative restriction or a measure having equivalent effect. In any event, it may be commercially rational for a market operator to take into account ostensibly non market considerations when exercising purchasing options, since such non market considerations may influence the purchasing choices of customers of the market operator. Thus, the supermarket giving preference to local produce may improve its market position with consumers who wish, for a variety of reasons (e.g., environmental reasons, protecting local jobs), to purchase local produce. Disentangling market and non market considerations could be difficult in such circumstances.

It seems that, in principle, discriminatory purchasing choices by a private market operator should fall outside the scope of Article 28 EC, even if the private operator holds a significant market position. Advocate General Maduro seems to distinguish between discrimination by private market operators holding insignificant market positions (he gives the example of an individual shopkeeper), and discrimination by private market operators holding significant market positions. This is a possible solution, but the present writer is not convinced it is correct. In the absence of collective action, which could be regarded as aiming to regulate the market, discriminatory purchasing decisions by private market operators would not seem to fall within the scope of Article 28 EC.

There are policy reasons for supporting this conclusion. Placing private market operators at risk of legal action by potential vendors of imported goods would place excessive burdens on potential purchasers of such products. Reference has already been made to the difficulty of 
disentangling market considerations from non market considerations in this context. Even though they would be free to justify decisions favouring domestic products on commercial grounds, the risk of being forced to do so in the course of litigation could force purchasers into 'defensive purchasing' practices, which could lead in practice to adherence to the transparency obligations incumbent on State purchasing bodies. The duty of transparency arises when State bodies wish to place a contract of sufficient significance to be of interest to out of State operators. The duty of transparency results from the duty on such State bodies not to discriminate indirectly against out of state operators in the award of contracts, and requires such bodies to publish a sufficiently accessible advertisement prior to the award of a contract, in order to open the contract award to competition and allow the impartiality of procurement remedies to be reviewed. ${ }^{76}$ If private market operators were obliged not to discriminate in their purchasing choices against imports, they would seem to be bound by the same transparency obligations as State purchasing bodies, leaving aside any question of 'defensive purchasing' referred to above.

Imposing a duty on private market operators not to discriminate in purchasing choices would extend Community legislative competence significantly. It would follow that the Community institutions could lay down rules to be followed by private market operators when making purchasing choices, analogous to those laid down by Community rules for State authorities, and State financed and controlled authorities. Since the present writer considers that Community competence to regulate the internal market should be subject to reasonable limitations, the latter consideration is regarded as arguing against horizontal application of Article $28 \mathrm{EC}$ in the present context. The foregoing considerations support the conclusion that even private market operators holding significant positions on the market should not be bound by the horizontal application of Article $28 \mathrm{EC}$ when they make purchasing choices.

It might be said that the position would be different if a private operator chose to undertake a competitive procurement exercise by inviting certain operators to express interest in a contract, or by advertising a contract specification and inviting bids. It might be said that this would amount to a sufficient regulation of the market to attract the application of Article $28 \mathrm{EC}$, so that direct or indirect discrimination against imports would and should be prohibited. The present writer does not consider that steps taken to solicit expressions of interest or bids from potential

${ }_{76}$ Case C-324/98 Teleaustria [2000] ECR I-10745 para 62; Case C-231/03 Coname [2005] ECR I-7287 paras 16 to 19; Case C-458/03 Parking Brixen, [2005] ECR I-8585 para 49; and see Commission Interpretative Communication on the Community law applicable to contract awards not fully subject to the provisions of the Public Procurement Directives [2006] OJ C 179/2. 
suppliers amounts in itself to regulation of the market for the purposes of the horizontal application of Article 28 EC. The 'rules' applied by the potential purchaser are not in any way extrinsic to the market, but are on the contrary a feature of normal market behaviour, even if the potential purchaser takes decisions within the framework of those rules which amount on the face of it to direct or indirect discrimination against imports. Take for example a situation where a potential purchaser invites expressions of interest in the supply of certain components by means of an advertisement on a website. This provokes expressions of interest from a number of potential suppliers, including some who manufacture the components in other Member States. Suppose the potential purchaser enters into negotiations solely with those market operators expressing interest who have in the past satisfactorily supplied the needs of the potential purchaser in question, and suppose those market operators all supply components produced in the same Member State as the potential purchaser. This latter choice has the effect of excluding imports from the potential purchasing decision. But it would be wrong to describe such discrimination in the course of the competitive tendering exercise as amounting to regulation of the market. And from the policy point of view, it would be excessively burdensome to place private operators in such circumstances at risk of a challenge by a potential supplier of goods produced in another Member State. The outcome of subsequent court proceedings would seem to depend on whether or not the market operator's decision to confine its attention to its previous suppliers was a decision which could be on the facts be regarded as falling within the scope of normal market behaviour. Confining consideration to tried and tested suppliers would often be an entirely cost effective and rational way to proceed. The costs of requiring market operators to litigate in order to defend their purchasing choices would seem to outweigh potential benefits. The present writer considers that the latter consideration argues against purchasing choices being subject to Article $28 \mathrm{EC}$ even if a private market operator directly discriminates against imports by requiring suppliers to supply only domestically produced goods.

Reference has already been made to the Mangold case, which establishes the horizontal effect of the general principle of equality. It might be argued that this principle argues in favour of making potential purchasers accountable for discriminatory procurement decisions, even if they are private market operators. It is argued above that purchasing decisions of private market operators do not fall within the scope of Article 28 EC. There seem to be no obvious reasons for concluding that such purchasing decisions nevertheless fall within the scope of Community law for the purposes of application of the general principle of equality. And the policy considerations referred to above argue against this conclusion. 


\section{The Treaty should be applied to discriminatory sales choices by private market operators}

The present writer would however draw the opposite conclusion as regards sales choices by private operators, such as shops or supermarkets, which discriminate on grounds of nationality, or by reference to the residence of potential purchasers, in the supply of goods. It would not seem to be excessively burdensome to impose on private operators the obligation not to depart from their normal terms and conditions of sale in the case of non nationals and non residents, unless such departure represented normal market behaviour. Whereas imposing an obligation of non discrimination on purchasers would impose a positive obligation to take account of the position of imports, an obligation of non discrimination on purchasers would amount to a negative obligation not to depart from normal business practice except on normal commercial grounds. This would be conducive to achieving the aims of the internal market, without imposing excessive obligations on private operators. Any resulting increase in Community competence would be justified by these same considerations. This conclusion, however, is to be derived from the horizontal effect of the general principle of equality, in conjunction with Article $28 \mathrm{EC}$, rather than from Article $28 \mathrm{EC}$ alone. The question of the imposition of duties of non discrimination on private market operators, such as shops and supermarkets, in the supply of goods, is considered further below, in conjunction with consideration of the imposition of similar duties as regards the supply of services by private market operators such as hotels etc.

\section{The horizontal scope of Article 39 EC}

Walrave and Koch holds that the prohibition of discrimination in Article 39 EC applies not only to the action of public authorities but also to rules of any other nature aimed at regulating gainful employment in a collective manner. ${ }^{77}$ But the horizontal scope of Article $39 \mathrm{EC}$ is not confined to situations where private action regulates employment collectively. The latter Article, which prohibits, inter alia, discrimination on grounds of nationality as regards pay and conditions of employment, does not appear to be aimed solely at State action, nor indeed collective action by private operators, and on the face of it the Article catches discrimination by individual employers, whether that discrimination is dictated by national legislation, or private prejudice.

\footnotetext{
77 Case 36/74 Walrave and Koch [1974] ECR 1405 paras 16, 17 and 22. See also Case C415/93 Union Royale Belge des Sociétés de Football Association ASBL v. Jean-Marc Bosman [1995] ECR I-4921 paras 82 to 84.
} 
That is indeed the conclusion confirmed by the Court's case law, in particular in the Angonese case. ${ }^{78}$ Similar considerations apply to equal pay for men and women as apply to Article $39 \mathrm{EC}$. Article $141 \mathrm{EC}$ requires Member States to ensure implementation of the principle of equal pay for men and women - the aim of that provision is to give rights to employees to receive the same pay for work of equal value irrespective of sex. On the face of it is this provision has the aim of placing obligations on the employers not to discriminate between men and women, as the Court of Justice held in Defrenne $v$ Sabena. ${ }^{79}$

\section{The horizontal scope of Article 49 EC}

\section{Article 49 EC does not prohibit discrimination by service providers against service recipients}

Walrave and Koch holds that the prohibition of discrimination in Article $49 \mathrm{EC}$ applies not only to the action of public authorities but also to rules of any other nature aimed at regulating the provision of services in a collective manner. ${ }^{80}$ Article 49 EC prohibits 'restrictions on freedom to provide services within the Community... in respect of nationals of Member States who are established in a State of the Community other than that of the person for whom the services are intended.' The Court of Justice has observed that Article $49 \mathrm{EC}$ do not draw any distinction as to the source of the restrictions on free movement which are to be abolished or prohibited.$^{81}$ Nevertheless, on the face of it, the wording of Article 49 EC appears to be aimed at regulatory measures (whether public or private) which might prevent market operators established in one Member State from providing services to customers established in another. Recipients of services might derive rights from the prohibition of restrictions on the freedom of providers, but only because giving rights to recipients is a necessary means of ensuring the rights of providers; in Luisi and Carbone the Court describes the right of a recipient of a service to travel to another Member State as the necessary corollary of the right of the service provider, and fulfils the objective of liberalising gainful activity by way of provision of services. ${ }^{82}$ This analysis would suggest that discrimination by a service provider against a service recipient would not be covered by Article 49, since no restriction would be being placed on the former's freedom to provide a service to the latter.

78 Case C-281/98 Angonese [2000] ECR I-4139 para 32.

79 Case 43/75 Defrenne $v$ Sabena [1976] ECR 455 paras 31 and 39.

80 Case 36/74 Walrave and Koch [1974] ECR 1405 paras 17, 18 and 20.

81 Case 36/74 Walrave and Koch [1974] ECR 1405 para 20.

82 Joined cases 286/82 and 26/83 Graziana Luisi and Giuseppe Carbone v. Ministero del Tesoro. [1984] ECR 377 para 10. 


\section{The general principle of equality in conjunction with Article 49 EC prohibits discrimination by service providers against recipients}

However, for the reasons given above in the context of the discussion of Mangold, account must be taken of the general principle of equality, and in particular the general prohibition on discrimination on grounds of nationality, within the scope of application of the Treaty, laid down in Article 12 EC. In the Cowan case the Court of Justice endorsed the proposition that a tourist from one Member State visiting another Member State was covered by Article $49 \mathrm{EC}$ as a service recipient. Being thus in a situation covered by Community law, Article 12 required that he "be placed on a completely equal footing' with nationals of the Member State in question. ${ }^{83}$ He was thus entitled to claim compensation from public funds for an assault which took place during his visit, on the same basis as French nationals. ${ }^{84}$ The Court in the Eberhard Haug-Adrion case proceeded on the basis that the prohibition of discrimination in Article $12 \mathrm{EC}$ and Article $49 \mathrm{EC}$ might apply to premiums charged by an insurance company to its customers if the premiums discriminated on grounds of nationality. ${ }^{85}$ The Mangold case, referred to above, supports this approach, since it upholds the horizontal direct effect of the general principle of equality; which includes the prohibition of discrimination on grounds of nationality. ${ }^{86}$

The provision of services by service providers to service recipients resident in a different Member State falls within the scope of Community law. For a service provider to refuse on grounds of nationality to supply a service to visiting nationals of other Member States would on the face of it seem to be incompatible with the horizontal effect of the fundamental principle of equality. It would seem to follow that, for example, hotels, and other service providers in a Member State, which refused to deal with visiting nationals of other Member States, would in principle be caught by the horizontal effect of the general principle of equality, in conjunction with Article 49 EC.

It might also be the case that discrimination by hotels and other service providers against resident nationals of other Member States would be incompatible with the general principle of equality. In the Phil Collins case the Court held that copyright and related rights, are subject

\footnotetext{
83 Case 186/87 Cowan v. Trésor Public [1989] ECR 195 para 10.

84 Case 186/87 Cowan v. Trésor Public [1989] ECR 195.

85 Case 251/83 Eberhard Haug-Adrion v Frankfurter Versicherungs-AG [1984] ECR 4277. The Court pronounced the premiums to be non discriminatory since they were based on 'objective actuarial factors'. See para 16 of judgment.

86 Case C-309/89 Codorníu SA v Council of the European Union [1994] ECR I-1853 para 26.
} 
to the general principle of non discrimination laid down by Article $12 \mathrm{EC}$, by virtue of their being subject to, inter alia, Articles $28 \mathrm{EC}$ and Article 49 EC, and thereby falling within the scope of operation of the Treaty, without there being any need to connect them in a particular case with the specific provisions of Article 28 and 49 EC. ${ }^{87}$ The analogous argument can be made that if the provision of services by service providers to service recipients falls within the scope of Community law in the cross frontier situations covered by Article 49 EC, that relationship falls within the scope of Community law for the purposes of Article $12 \mathrm{EC}$, without there being any need to connect that relationship in a particular case with Article 49 EC. If that argument is correct, it would indeed lead to the conclusion referred to above, that it would be contrary to the general principle of equality for hotels etc to discriminate against not only visiting nationals of other Member States, but also resident nationals of other Member States.

Support for this line of argument, as regards individuals if not undertakings and companies, is to be found in the concept of EU citizenship, and the case law thereon. In Martinez Sala the Court held that a national of one Member State lawfully resident in the territory of another was entitled to rely on Article $12 \mathrm{EC}$ to claim equality in all situations falling within the material scope of Community law. ${ }^{88}$ A situation fell within the material scope of Community law if the situation was covered by Community rules applicable to cross-border situations, even if those rules did not apply to the situation in issue. ${ }^{89}$ The reasoning is similar to that in Phil Collins, and in truth the general line of reasoning in Martinez Sala would not seem to be dependent upon the concept of EU Citizenship.

\section{The general principle of equality in conjunction with Article 28 EC prohibits discrimination by shops, supermarkets etc.}

A similar argument could be made if shops or supermarkets engaged in such discrimination as regards the supply of goods. The Court's case law establishes that residents of one Member State visiting the territory of another to purchase goods fall within the scope of Article $28 \mathrm{EC}$ and are entitled in principle to the shop under the same conditions as the local population. As the Court says in GB-INNO-BM:

\footnotetext{
87 Joined Cases C-92/92 and C-326/92 Phil Collins [1993] ECR I-5145 paras 21 to 28.

88 Case C-85/96 Maria Martinez Sala [1998] ECR I-2691.

89 Case C-85/96 Maria Martinez Sala [1998] ECR I-2691 paras 26 to 28. For a convincing criticism of, inter alia, the Court's approach to the "material scope" of Community law, see Eleanor Spaventa, 'Seeing the wood despite the trees? On the scope of Union Citizenship and its constitutional effects,' (2008) 45 CML Rev. 13-45.
} 
Free movement of goods concerns not only traders but also individuals. It requires, particularly in frontier areas, that consumers resident in one Member State may travel freely to the territory of another Member State to shop under the same conditions as the local population. ${ }^{90}$

It would seem to follow that it would be contrary to the general principle of equality, and in particular Article $12 \mathrm{EC}$, for shops or supermarkets to discriminate against visiting nationals of other Member States or resident nationals of other Member States.

\section{The position is analogous for discrimination on racial grounds in the supply of goods or services to the public}

It is to be noted that if the foregoing arguments are correct, the result would be to align legal protection against discrimination on grounds of nationality, with that accorded against discrimination on grounds of racial or ethnic origin under Council Directive 2000/43/EC, Article 3(1)(h) of which (in conjunction with Articles 1 and 2) prohibits discrimination inter alia as regards 'access to and supply of goods and services which are available to the public...'. Article 3(1) of the Directive makes it clear that it applies to the supply of goods and services by both the public and private sectors. The fact that private operators are prohibited from discriminating against potential customers on grounds of racial or ethnic origin suggests that it would not be excessively burdensome to accord similar protection to non-nationals, or indeed, non-residents.

\section{Justifying discrimination by service providers against non resident recipients}

It is appropriate to give further consideration to the position of a service provider discriminating against a recipient resident in another Member State. If it is the case that such discrimination is contrary to the general principle of equality, in conjunction with Article $49 \mathrm{EC}$, then the horizontal effect of these provisions would seem to apply to service providers refusing to provide services to customers on the ground that they are resident in a different Member State, and to service providers providing services to such customers on discriminatory terms. It will be noted that the Eberhard Haug-Adrion case, referred to above, concerned the latter situation, viz., an insurance company in Germany allegedly discriminating against a customer resident in Belgium. In each of the cases referred to - refusal to provide a service, or provision but on discriminatory terms, questions of justification could arise. The Court of Justice

90 Case C-362/88 GB-INNO-BM [1990] ECR I-667 para 8. 
held in Ciola that national rules which discriminate by reference to the place of residence of the recipient of services can be justified only by an express derogation such as Article $46 \mathrm{EC} .{ }^{91}$ It will be recalled that the latter Article provides for derogations from the freedom to provide services on grounds of public policy, public security or public health. In Bosman ${ }^{92}$ the Court of Justice, referring to the application of Article $43 \mathrm{EC}$ to the rules of sporting associations, held that individuals could rely on justifications on grounds of public policy, public security or public health; neither the scope nor the content of those grounds of justification was in any way affected by the public or private nature of the rules in question..$^{93}$ In Laval, ${ }^{94}$ the Court took a different approach, and held that grounds of public policy could only be relied upon by public bodies. ${ }^{95}$ It follows that service providers discriminating against service recipients cannot be required by the ruling in Ciola to justify their conduct by reference to public policy, public security or public health.

In Viking, the Court held that a trade union could justify collective action restricting the exercise of a fundamental freedom by recourse to overriding reasons of public interest, such as the protection of workers. The option of relying upon overriding reasons of public interest might be open to service providers seeking to justify discrimination against recipients residing in other Member States. But a more straightforward option might be available. In Eberhard Haug-Adrion the Court held that offering a reduced no-claims bonus in respect of cars with customs plates was justified on actuarial grounds. It seems, then, that a service provider seeking to justify a refusal to provide a service to a recipient in another Member State, or seeking to justify dealing on terms which are discriminatory compared to terms offered to recipients in the same State, may do so in one of two ways. The first is on the basis that from the commercial point of view there is no discrimination at all - as in the Eberhard Haug-Adrion case. In such a case the service provider may say that for commercial reasons it is not profitable to provide its service beyond the borders of the Member State in which it is located, or that the different terms offered reflect differences in costs or other factors relevant to pric-

\footnotetext{
91 Case C-224/97 Ciola v. Land Vorarlberg [1999] ECR I-2517 para 16. And see generally D Wyatt, A Dashwood and others, Wyatt and Dashwood's European Union Law, (5 ${ }^{\text {th }}$ edn, Thomson/Sweet and Maxwell, London 2006) 19-039 and 19-040.

92 Case C-415/93 Union Royale Belge des Sociétés de Football Association ASBL v. JeanMarc Bosman [1995] ECR I-4921.

93 Case C-415/93 Union Royale Belge des Sociétés de Football Association ASBL v. JeanMarc Bosman [1995] ECR I-4921 para 86.

94 Case C-341/05 Laval, Judgment of 18 December 2007.

95 Laval para 84. The Court does not refer to its observation in Bosman, despite the fact that Advocate General Mengozzi draws the opposite conclusion, citing Bosman. See Opinion para 284.
} 
ing the service for recipients in other Member States. It will be recalled that it was argued at the outset that normal market behaviour designed to improve the market position of one economic operator should not in principle be held to amount to a restriction on the fundamental freedom of another market operator. As noted above, a service provider might also seek to justify discriminatory treatment of out of State recipients on the basis of overriding reasons of public interest. It is perhaps worthy of note that the overriding reason of public interest referred to in Viking - the protection of workers - is itself also a private economic interest, in as much as the collective action pursued by the trade union and international federation of trade unions concerned was aimed at furthering the economic interests of trade union members. It is perhaps likely that private market operators will most readily be able to invoke those overriding reasons of public interest which also reflect their commercial interests, such as, for example, the protection of intellectual property rights. It seems inevitable that the kind of justifications which a private market operator will seek to rely upon in this context will be, in one way or another, economic justifications, although in the case of action by State authorities, derogation from fundamental freedoms on economic grounds is not in principle permissible. ${ }^{96}$

It is argued above that purchasing choices of private operators relating to goods and services do not fall within the scope of Community law for the purposes of the general principle of equality, but that sales choices do. It is argued that this distinction is supported by policy considerations, in particular the consideration that it would be excessively burdensome to impose on private operators the obligation not to favour domestic products in their purchasing decisions. Even though they would be free to justify decisions favouring domestic products on commercial grounds, the risk of being forced to do so in the course of litigation could force purchasers into 'defensive purchasing' practice which could lead in practice to adherence to the transparency obligations of state purchasing bodies. The threat of litigation might even lead some market operators to believe that it was safer to buy imports than domestic products.

It would not seem, however, to be excessively burdensome to impose on private operators the obligation not to depart from their normal terms and conditions of sale in the case of non nationals or non residents, unless such departure represented normal market behaviour. Whereas an obligation of non discrimination on purchasers would amount to a positive obligation to take account of the position of imports, an obligation of

\footnotetext{
96 See Wyatt and Dashwood (n 91) 20-049, where it is argued that while 'economic aims' in the sense of protectionist aims clearly cannot justify derogation from fundamental freedoms, it is less clear why non protectionist economic aims, such as avoidance of erosion of the tax base, cannot do so.
} 
non discrimination on purchases would amount to a negative obligation not to depart from normal business practice except on normal commercial grounds. It is also argued above that recognising Community competence to regulate such discrimination would be conducive to achieving the aims of the internal market, without imposing excessive burdens on private market operators.

\section{A possible case in point - excessive 'roaming' charges}

A possible example of discriminatory service provision contrary to the general principle of equality and in particular to Article $12 \mathrm{EC}$ is that of excessive 'roaming' charges, which have been recently regulated by Regulation (EC) No 717/2007 of the European Parliament and Council. A mobile telephone user is a 'roaming' customer when that customer has a contract with a home provider which permits him or her to make or receive calls on a visited network in another Member State, by means of arrangements between the home provider and the operator of that visited network. The visited network makes charges ('wholesale' charges) to the home provider, for allowing the roaming customer to use the visited network, and the home provider makes charges ('retail' charges) to its customer. The reason for the adoption of an EC Regulation regulating these wholesale and retail charges was that such charges were regarded as being excessive, in the sense of the margin between costs and prices being wider than would prevail in fully competitive markets. ${ }^{97}$ The excessive retail charges were regarded as resulting from high wholesale charges levied by the foreign host network operator and also, in many cases, from high retail mark-ups charged by the customer's own network operator. ${ }^{98}$ The preamble noted that 'reductions in wholesale charges are often not passed on to the retail customer. ${ }^{99}$ Accordingly, the Regulation imposes regulatory obligations at both retail and wholesale level, to protect the interests of roaming customers. These regulatory obligations comprise a maximum average wholesale charge, and a maximum retail charge. ${ }^{100}$

There are two points to make about the situation prevailing prior to the adoption of Regulation 717/2007 which seem relevant to the present discussion. The first is that the markets in question were not fully competitive markets. This resulted at least in part from the fact that roaming services at retail level are not purchased independently but constitute only one element of a broader retail package purchased by customers

97 See Regulation (EC) No 717/2007 preamble, recital (1).

98 See Regulation (EC) No 717/2007 preamble, recital (1).

99 See Regulation (EC) No 717/2007 preamble, recital (1).

100 See Regulation (EC) No 717/2007 in particular arts 3 and 4. 
from their home provider. ${ }^{101}$ The second point to be made is that the retail charges made to roaming customers by their home provider were discriminatory in comparison with domestic tariffs, being 'roughly four times higher than domestic tariffs. ${ }^{102}$ Since it appears that the excessive and discriminatory retail charges resulted at least in part from high wholesale charges, it seems likely that visited networks were imposing discriminatorily high wholesale charges on home operators. Assuming for the sake of argument that both forms of discrimination existed, they would seem to amount to infringements of the general principle of equality, in particular of Article 12 EC.

Counter arguments might be raised. In each case it might be said that the pricing behaviour of the network operators amounted to normal market behaviour; the market might not be fully competitive, but that simply means that market operators have more freedom in price fixing than they would otherwise have, and they naturally charge as much as they can. It is certainly the view of the present writer that normal market behaviour cannot amount to a breach of the general principle of equality. But a key question which arises is the extent to which a market operator can, or should be able to justify discrimination against out of state operators, or discrimination against customers solely because they have crossed a national frontier, on grounds of normal market behaviour, when market conditions are not normal, and the market is not 'fully competitive'? It has been argued above that market operators should be permitted to justify discrimination by reference to cost or other considerations which in effect rebut the original inference of discrimination. But the case under consideration - roaming charges - is rather different.

If it is correct that the regulation of roaming charges is in fact an attempt to eliminate discrimination on grounds of nationality and residence, it would not seem to be the first time that the Community lawmaker has employed legislation under Article $95 \mathrm{EC}$ for this purpose. Regulation (EC) No 2560/2001 on cross-border payments in euro, lays down rules on such payments in order to ensure that charges for those payments are the same as those for payments within a Member State. The preamble states that the fact that the level of charges for cross-border payments continues to remain higher than the level of charges for internal payments 'is hampering cross-border trade and therefore constitutes an obstacle to the proper functioning of the internal market'. ${ }^{103}$ The conduct complained of however is the conduct of private parties which discriminates on grounds of nationality and/or residence. The explana-

\footnotetext{
101 See Regulation (EC) No 717/2007 preamble, recital (7).

102 SEC(2006) 926, Commission Staff Working Paper - Executive Summary 2.

103 Recital 6.
} 
tory memorandum to the Commission Proposal for the Regulation refers to discriminatory charges for the use of cash machines by out of State residents as an example of the mischief the Directive is designed to correct. ${ }^{104}$

A related issue which arises as regards roaming charges is that of the competence of the Community to adopt Regulation 717/2007 under Article $95 \mathrm{EC}$. The use of Article $95 \mathrm{EC}$ as a legal base for such a measure was questioned prior to its adoption. ${ }^{105}$ The preamble does not overtly address the question of competence, though it implies that the pricing rules it contains will ensure the smooth functioning of the internal market for roaming services. ${ }^{106}$ Normal grounds for regulation under Article $95 \mathrm{EC}$ or other legal bases for regulating the internal market are that disparities between national rules create obstacles to the free movement of goods or services, or appreciable distortions of competition, or create uncertainty or 'psychological obstacles' to individuals or undertakings engaged in cross-border economic activities. ${ }^{107}$ It is not at all obvious that any of these grounds for regulation under Article $95 \mathrm{EC}$ exist. Nor can it be said to be established that the fact that market operators are engaged in economic activity in a market which is not 'fully competitive' creates an appreciable distortion of competition justifying harmonisation under Article 95 EC. It is not surprising that the validity of the Regulation has been challenged. In Telefonica $\mathrm{O} 2$ and others $v$ Secretary of State for Business and Regulation Reform the claimants argued before the Administrative Court in London that the Regulation adopts it is believed uniquely, a centralised price control divorced from Article 95 and the requirement to remove distortions in and obstacles to competition within the internal market.' ${ }^{108}$ The Administrative Court referred questions to the Court of

\footnotetext{
${ }^{104}$ See COM(2001) 439 final, Proposal for a Regulation on cross-border payments in euro, para 3.

105 Questions have been raised as to the competence of the Community institutions to adopt the Regulation in question under art 95 EC. See House of Lords EU Committee, $17^{\text {th }}$ Report of Session 2006-07, Mobile Phone Charges in the EU, Curbing the Excesses, Vol 1: The Report, HL Paper 79-1 paras 24, 62, and page 32, referring to objections to the legal base by Orange and Vodaphone, and to legal opinions from Sir Francis Jacobs QC and David Murray (of 16 October 2006), and from Claus-Dieter Ehlerman (of 27 March 2006).

106 See Regulation (EC) No 717/2007 preamble, recital (4).

107 See, generally, DA Wyatt, 'Community Competence to Regulate the Internal Market' (2007) SSRN Oxford Legal Studies Research Paper No 9/2007 (e-pub); abridged version published in M Dougan and S Currie (eds), 50 Years of the European Treaties: Looking Back and Thinking Forward (Hart Publishing, Oxford 2008).

108 [2007] EWHC 3018 (Admin) para 11. The questions posed to the European Court are as follows: Is Regulation (EC) No 717/2007 invalid, in whole or in part, by reason of the inadequacy of art $95 \mathrm{EC}$ as a legal basis? Is art 4 of Regulation (EC) No 717/2007 (together with arts 2(a) and 6(3) insofar as they refer to the Eurotariff and obligations relating to the Eurotariff) invalid on the grounds that the imposition of a price ceiling in respect of retail roaming charges infringes the principle of proportionality and/or subsidiarity?
} 
Justice of the European Communities under Article 234 EC asking inter alia whether the Regulation was invalid in whole or in part by reason of the inadequacy of Article $95 \mathrm{EC}$ as a legal base. ${ }^{109}$

It is noted above, however, that it is arguable that the possible discrimination referred to above regarding roaming charges is contrary to the general principle of equality, in particular discrimination on grounds of nationality, and by reference to the residence of customers. If this argument is correct, it would mean that the correct procedure had been used for the regulation of wholesale roaming charges. If visited network operators charged home network operators on a basis that amounted to indirect discrimination on grounds of nationality contrary to Article 12 EC, competence to prohibit such discrimination could be based on Article 12 EC. The applicable procedure would be that laid down in Article 251 $\mathrm{EC}$, which is the same procedure as that specified for recourse to Article $95 \mathrm{EC}$. The failure to refer to Article $12 \mathrm{EC}$ as a Treaty base would not necessarily be an error which would affect the validity of the Regulation. ${ }^{110}$ But the question of competence to regulate retail roaming charges raises more difficult issues. The discrimination involved is not discrimination based on nationality, but discrimination based on the fact that the roaming customer is having a service provided in a Member State other than that of his or her residence, and other than that of the retail provider. This amounts to discrimination on grounds of residence, contrary to the general principle of equality, which falls within the scope of application of the Treaty, since it falls within the scope of Article $49 \mathrm{EC}$; the Court has held that Article 49 of the Treaty 'applies not only where a person providing services and the recipient thereof are established in different Member States, but also in cases where the person providing services offers those services in a Member State other than that in which he is established, wherever the recipients of those services may be established. ${ }^{111}$ It is not clear, however, that this situation can be regulated by the Community institutions under Article $95 \mathrm{EC}$, and the present writer doubts that such a conclusion would be correct. The situation does not fall within the scope of Article $49 \mathrm{EC}$ alone, since the latter Article alone does not prohibit discrimination by service providers against service recipients; that is prohibited by the general principle of equality in conjunction with Article 49 EC. While that part of the general principle of equality which covers discrimi-

\footnotetext{
109 The case is listed as Case C-58/08.

110 Cf Case C-491/01 $R v$ Secretary of State for Health ex parte BAT and Imperial Tobacco [2002] ECR I-11453 paras 103-111 (superfluous reference to art 133 EC does not vitiate the procedure for adopting a Directive properly based on art 95 since the correct procedure - art 251 EC procedure - is used).

111 C-198/89 Commission v. Greece [1991] ECR I-727 paras 8 to 10; Case C-398/95 Syndesmos ton en Elladi Touristikon kai Taxidiotikon Grafeion v. Ypourgos Ergasias [1997] ECR I-3091 para 8.
} 
nation on grounds of nationality is subject to Community competence under Article $12 \mathrm{EC}$, by means of the procedure in Article $251 \mathrm{EC}$, other aspects of the general principle of equality, other than the sex equality provisions in Article $141 \mathrm{EC}$, which are also subject to the procedure in Article $251 \mathrm{EC}$, are subject to Community competence under either Article $13 \mathrm{EC}$, or Article $308 \mathrm{EC}$. The former Article covers discrimination on grounds of sex, racial or ethnic origin, religion or belief, disability, age or sexual orientation, and Community action is subject to unanimity in Council and to consultation of the European Parliament. Legislation to prohibit other forms of discrimination may be undertaken under Article $308 \mathrm{EC}$, where it is necessary to do so in the course of operation of the common market, by the same procedure. ${ }^{112}$ The Council of the EU has determined that discrimination based on religion or belief, disability, age or sexual orientation may undermine the achievement of the objectives of the EC Treaty, including the free movement of persons. ${ }^{113}$ It would seem to follow that Article $308 \mathrm{EC}$ provides competence to regulate retail roaming charges, since discriminatory charges place roaming customers at a disadvantage for having exercised their rights of free movement, and rectification of that disadvantage is necessary to attain the objective of freedom of movement. ${ }^{114}$ This latter objective is, moreover, one, inextricably linked to the course of operation of the common market. If the foregoing is correct, it would follow that a Regulation on roaming charges could be validly adopted as regards the regulation of wholesale roaming charges on the basis of Article $12 \mathrm{EC}$, pursuant to the procedure in Article $251 \mathrm{EC}$, but such a Regulation could not validly regulate retail roaming charges, the legal basis for which would be Article 308 EC. The effect of the case law on combining Treaty bases would seem to be that Regulation (EC) No 717/2007 on roaming charges should have been based on Article 308 EC. The main aim of the Regulation is clearly to ensure that users of public mobile telephone networks do not pay excessive prices for Community- wide roaming services. ${ }^{115}$ In order to achieve this aim, retail prices are subject to control. ${ }^{116}$ Since one of the causes of excessive retail charges is excessive wholesale charges, the latter are also subject to con-

\footnotetext{
112 Art 308 EC provides: 'If action by the Community should prove necessary to attain, in the course of the operation of the common market, one of the objectives of the Community and this Treaty has not provided the necessary powers, the Council shall, acting unanimously on a proposal from the Commission and after consulting the European Parliament, take the appropriate measures.'

113 Council Directive 2000/78/EC establishing a general framework for equal treatment in employment and occupation, preamble, recital (11).

114 But not under art $95 \mathrm{EC}$, since art 95(2) EC excludes from the scope of art 95(1) EC provisions relating to the free movement of persons.

115 Recital (1) to preamble art 1.

116 Art 4.
} 
trol. ${ }^{117}$ It might be possible to conclude that the control of retail charges comprises the main or predominant purpose or component of the Regulation, and that the control of wholesale charges is merely incidental; alternatively, and more convincingly, the two objectives are inseparably linked. If either analysis is correct, Article $308 \mathrm{EC}$ is the appropriate legal basis, rather than Article 95 EC. ${ }^{118}$

It is to be noted, however, that the Court of Justice does not take a rigorous approach towards questions of competence under Article $95 \mathrm{EC}$, and it is likely that the Court will endorse fairly general arguments justifying the use of Article 95 EC. ${ }^{119}$ Similar questions as to the appropriate Treaty base for the Regulation on roaming charges would seem to arise in respect of Regulation (EC) No 2560/2001 on cross-border payments in euro.

\section{Horizontal effect of Article 56 EC - capital and payments}

Within the framework of the Chapter on capital and payments, all restrictions on the movement of capital and on payments between Member States and between Member States and third countries are prohibited. ${ }^{120}$ These provisions are without prejudice to the right of Member States to apply relevant provisions of their tax law which distinguish between taxpayers who are not in the same situation with regard to their place of residence or with regard to the place where their capital is invested. ${ }^{121}$ A general argument in favour of the horizontal effect of Article $56 \mathrm{EC}$ is that it does not draw any distinction as to the source - public or private - of the restrictions which it prohibits. In the case of other Treaty Articles, such as Articles $39 \mathrm{EC}$ and $49 \mathrm{EC}$, the Court has regarded it as a factor favouring the possibility of horizontal effect that these provisions do not draw any distinction as to the source of the restrictions on free movement which are to abolished or prohibited. ${ }^{122}$ It is suggested above that Article $28 \mathrm{EC}$ applies horizontally solely to that private action which seeks to regulate trade or the transit of goods in a way analogous to the ways in which State authorities regulate trade or the transit of goods, and it is possible that the same conclusion should be adopted for Article 56 EC. The present writer inclines, however, to the view that Article 56

\footnotetext{
117 Recital (1) to preamble art 3.

118 Case C-338/01 Commission v Council [2004] ECR I-4829.

119 See, generally, Wyatt (n 107).

120 Art 56 EC.

121 Art 58(1)(a) EC.

122 Case C-281/98 Angonese [2000] ECR I-4139 para 30; Case 36/74 Walrave and Koch [1974] ECR 1405 para 20.
} 
EC should be read as having solely vertical effect. ${ }^{123}$ This is based on policy grounds. Article 56 EC applies to movement of capital between Member States and third countries as well as between Member States. It has been held to be directly effective in these respects. ${ }^{124}$ Excluding horizontal direct effect would prevent private operators in Member States being vulnerable to actions at the suit of third country market operators in circumstances where it is unlikely that such third country operators would be similarly vulnerable. ${ }^{125}$ It is argued below that the position of market operators in Member States could be safeguarded by application of the general principle of equality; but that the protection of this principle should not be extended to nationals of third countries resident in third countries.

Although the Treaty does not define the terms 'movement of capital' and 'payments', the case law of the Court of Justice has indicated that Directive 88/361, ${ }^{126}$ together with the nomenclature annexed to it, may be used for the purposes of defining what constitutes a capital movement. ${ }^{127}$ It follows that capital movements include, for example, investing in a new or existing undertaking with a view to controlling and managing that undertaking, and investing in real property in national territory by non-residents. Thus, for example, national measures which discourage residents of one Member State from purchasing land in the territory of another infringe Article 56 EC. ${ }^{128}$ On the basis of the arguments developed above in connection with Article $49 \mathrm{EC}$, it is possible to conclude that the general principle of equality, in conjunction with Article 56 EC, would prohibit, for example, provisions of the constitution of a company incorporated in a Member State which exclude nationals of other Member States from acquiring shares in the company. While Article 56 applies to capital movements between Member States and between Member States and third countries, it cannot be assumed that the general principle of equality, and in particular the prohibition of discrimination on grounds

\footnotetext{
123 Usher argues that art 73b EC, prohibiting restrictions on capital movements between Member States and Member States and third countries, might be regarded as having horizontal effect, at any rate as regards capital movements between Member States. See Usher, The Law of Money and Financial Services in the European Community (Clarendon Press, Oxford 1994) 26, 27.

124 Joined Cases C-163/94, C-165/94 and C-250/94 Sanz de Lera and Others [1995] ECR I-4821.

125 The Court has given weight to generally analogous considerations in the context of WTO obligations. See Wyatt, Dashwood and others (n 91) 5-044.

126 [1988] OJ L 178/5.

127 Case C-222/97 Trummer and Mayer [1999] ECR I-1661 paras 20 and 21. See Wyatt, Dashwood and others (n 91) 20-012.

128 Case C-302/97 Konle [1999] ECR I-3099; Case C-370/05 Criminal proceedings against Uwe Kay Festersen [2007] ECR I-1129.
} 
of nationality in Article $12 \mathrm{EC}$, will apply to nationals of third countries resident in third countries as regards participation in the capital of a company registered in a Member State, and it considered that this possibility should be generally excluded on policy grounds. ${ }^{129}$ Further reference to restrictions on fundamental freedoms resulting from provisions of the corporate constitution is made in the context of Article $43 \mathrm{EC}$, below. It is also possible to conclude, on the basis of the arguments referred to above, that a refusal by a vendor of real property, for example a property developer marketing apartments in a new development in a Member State, to sell properties to residents of other Member States, would be contrary to the general principle of equality, in conjunction with Article 56 EC. The general principle of equality, in conjunction with Articles 39 and $43 \mathrm{EC}$, would seem to lead to the same conclusion as regards an employed or self-employed national of one Member State seeking to purchase housing or business premises in the territory of another. The same conclusion would seem to follow for all nationals of Member States resident in the territory of another, on the basis of the Court's case law in Phil Collins and Martinez Sala, referred to above. This would produce similar protection against discrimination on grounds of nationality in this context as is provided against discrimination on grounds of racial or ethnic origin under Directive 2000/43/EC, Article 3(1)(h) of which (in conjunction with Articles 1 and 2) prohibits discrimination on grounds of racial or ethnic origin as regards 'access to and supply of goods and services which are available to the public, including housing' (emphasis added). The Directive in question would also seem to prohibit provisions of a corporate constitution which discriminate on racial or ethnic grounds, and this point is discussed below in the context of Article $43 \mathrm{EC}$. Further reference will be made to capital movement, as appropriate, in the context of the discussion of Article 43 EC.

\footnotetext{
129 Art 57(1) provides that the provisions of Art 56 shall be without prejudice to the application to third countries of any restrictions which exist on 31 December 1993 under national or Community law adopted in respect of the movement of capital to or from third countries involving direct investment - including in real estate - establishment, the provision of financial services or the admission of securities to capital markets. Moreover, free movement of capital between Member States and free movement of capital between third countries cannot be entirely assimilated, since such movements take place in different legal contexts. See Case C-101/05 Skatteverket v A. Judgment of 18 December 2007, para 60. Thus, in Case C-446/04 Test Claimants in the FII Group [2006] ECR I-11753 para 171, the Court stated that it may be that a Member State will be able to demonstrate that a restriction on capital movements to or from third countries is justified for a particular reason in circumstances where that reason would not constitute a valid justification for a restriction on capital movements between Member States.
} 


\section{The horizontal scope of Article $43 \mathrm{EC}$ - provisions of the corporate constitution and action by directors as restrictions on freedom of establishment}

\section{Discriminatory provisions in the corporate constitution}

There seem to be strong grounds for considering that a provision of the corporate constitution prohibiting non nationals or non residents from acquiring shares in the company would be incompatible with (a) the general principle of equality, in particular the prohibition of discrimination on grounds of nationality in Article $12 \mathrm{EC}$, in conjunction with Article $56 \mathrm{EC}$, and (b) with Article $43 \mathrm{EC}$, either alone, or in conjunction with the general principle of equality/Article 12 EC. ${ }^{130}$

In the first place, the corporate constitution regulates collectively the terms and conditions upon which shares may be bought and sold. The purchase of shares falls within the scope of Article 56 EC, comprising either 'direct investment', where the acquisition of corporate control is involved, or 'portfolio investment' where it is not'. Direct investment is defined as follows by the Court of Justice in Commission v. Belgium: ${ }^{131}$

Points I and III in the nomenclature set out in Annex I to Directive $88 / 361$, and the explanatory notes appearing in that annex, indicate that direct investment in the form of participation in an undertaking by means of a shareholding or the acquisition of securities on the capital market constitute capital movements within the meaning of Article [56] of the Treaty. The explanatory notes state that direct investment is characterised, in particular, by the possibility of participating effectively in the management of a company or in its control.

Referring to the same Directive, the Commission describes 'portfolio investment' as follows in its 1997 Communication on Certain Legal Aspects concerning intra-EU Investment: ${ }^{132}$

In the Directive, the heading 'Acquisition . . . of domestic securities.' includes, among others, the transaction 'acquisition by non-residents' of shares and bonds in domestic companies on pure financial investment grounds, that is, without the aim of exerting any influence in the management of the company. Thus, this transaction is considered as a form of capital movement. It is also usually known in the financial literature as 'portfolio investment'.

It has been argued above that Article 56 EC could only have horizontal effect in circumstances where private action regulated capital

\footnotetext{
130 There is some discussion of this in Wyatt, Dashwood and others (n 91) 20-021.

131 Case C-503/99 [2002] ECR I-4809 para 38.

132 [1997] OJ C 220/15. See also The Commission's 2005 Communication on Intra-EU investment in the financial services sector [2005] OJ C 293/2.
} 
movement in the same way as state action regulates the market. This would allow for the possibility that a provision of a corporate constitution which excluded non residents from acquiring shares in the company would amount to sufficient collective regulation of the market in shares to attract the horizontal effect of Article 56 EC. As indicated above, however, the present writer inclines to the view that Article 56 EC should be construed as having solely vertical effect. The purchase of shares in a company incorporated in a Member State by residents of other Member States would however fall within the scope of Article 56 EC. Restrictions on such acquisition in the corporate constitution would amount to indirect discrimination on grounds of nationality contrary to Article 12 EC, and the latter Article would seem to be capable of horizontal effect in such circumstances. It would follow that nationals of Member States could rely on the horizontal effect of the Treaty in such circumstances, but nationals of third countries could not, unless resident in a Member State, in which case reliance might still be placed on the general principle of equality.

Article 43 EC aims to remove discriminatory restrictions on the pursuit of self employed activities and the management of undertakings. The Court has held that 'a national of a Member State who has a holding in the capital of a company established in another Member State which gives him definite influence over the company's decisions and allows him to determine its activities is exercising his right of establishment'. ${ }^{133}$ It follows that an individual or company seeking to acquire such a holding would also fall within the scope of the right of establishment. Would a provision of the corporate constitution prohibiting non nationals from acquiring shares in a company be incompatible with Article 43 EC?

Such a provision would regulate access to the self employed activity of management of a corporate undertaking, and it would seem to do so collectively, in the sense that the restriction would apply to all those holding shares, and to all those wishing to purchase shares from such persons with a view to acquiring control of the company in question. Article 7(4) of Regulation 1612/68/EEC nullifies clauses of individual or collective agreements concerning inter alia eligibility for employment which lay down or authorise discriminatory conditions in respect of workers who are nationals of other Member States. In Walrave and Koch the Court of Justice cites this provision in support of the proposition that Article 39 EC 'extends likewise to agreements and rules which do not emanate from public authorities'. ${ }^{134}$ The Court's reasoning in this respect is supported by its later judgment in Rutili, in which the Court holds that Regulation

\footnotetext{
133 Case C-251/98 C. Baars v Inspecteur der Belastingen Particulieren/Ondernemingen Gorinchem [2000] ECR I-2787 paras 21 and 22.

134 Case 36/74 Walrave and Koch [1974] ECR 1405 paras 21 and 22.
} 
1612/68/EEC does not create any new rights, but lays down the scope and detailed rules for the exercise of rights conferred directly by the Treaty. ${ }^{135}$ In Walrave and Koch the Court adds that the activities referred to in Article $49 \mathrm{EC}$ are not be distinguished by their nature from those in Article $39 \mathrm{EC}$, but only by the fact that they are performed outside the ties of a contact of employment. ${ }^{136}$ Precisely the same point of course holds good for Article $43 \mathrm{EC}$. If Article $39 \mathrm{EC}$ has horizontal effect as regards 'agreements and rules' which do not emanate from public authorities and which impose discriminatory rules regarding access to employed activities, it would seem to follow that Article $43 \mathrm{EC}$ has horizontal effect as regards rules laid down by agreement in a corporate constitution exclude non-nationals from the self-employed activity of managing a corporate undertaking. This line of argument receives further support from the fact that Article 8 of Regulation 1612/68/EEC guarantees equality for workers as regards membership of trade unions, and the exercise of rights attaching thereto such as voting rights. If Article $39 \mathrm{EC}$ grants equality to employed persons as regards membership and voting rights in private law bodies such as trade unions, it is difficult to see why Article 43 EC should not grant similar equality to self-employed persons as regards membership and voting rights in private law bodies such as companies.

The present writer would conclude that Article 43 EC prohibits discrimination on grounds of nationality in the provisions of corporate constitutions where the consequence is to prevent nationals of Member States from acquiring control of and taking part in the management of corporate bodies. Even if this effect could not be derived from Article 43 EC itself, it would seem to follow from Article $12 \mathrm{EC}$, since the purchase by a national of one Member State of a controlling shareholding in a company established in the territory of another falls within the scope of Article 43 EC.

If the foregoing conclusion is correct, it would seem that in this respect protection against discrimination on grounds of nationality is similar to protection against discrimination on racial or ethnic grounds under Directive 2000/43/EC, Article 3(1)(a) of which prohibits discrimination on racial or ethnic grounds as regards conditions for access to self-employment, and Article 14 of which requires Member States to declare null and void or amend inter alia the internal rules of undertakings.

\section{Non discriminatory restrictions in the corporate constitution}

If the foregoing argument is correct, to the effect that Article $43 \mathrm{EC}$ prohibits discriminatory provisions of the corporate constitution because

135 Case 48/75 Royer [1976] ECR 497 para 28.

136 Case 36/74 Walrave and Koch [1974] ECR 1405 para 23. 
Article $43 \mathrm{EC}$ has horizontal effect as regards contractual rules which collectively regulate eligibility for the conduct of self-employed activities, or contractual rules which establish and regulate private law bodies such as trade unions or companies, that horizontal effect is not necessarily confined to discriminatory provisions, but may apply also to non discriminatory provisions which hinder or make less attractive the exercise of a fundamental freedom, providing that the provisions in question are not a manifestation of normal market activity.

The Court of Justice seems to accept in the BAA case that trade in the shares of a company can comprise a market, restrictions on access to which may be incompatible with Article $56 \mathrm{EC}$ on capital movement. Considering provisions of the corporate constitution which limited any shareholder to a maximum holding of $15 \%$ of the equity shares in the company concerned, and which gave rights of prior approval over certain transactions (principally the sale of a designated airport, or winding up of the company) to a British government minister by virtue of his ownership of a single £1 'special share', the Court held:

In this instance, although the relevant restrictions on investment operations apply without distinction to both residents and non-residents, it must none the less be held that they affect the position of a person acquiring a shareholding as such and are thus liable to deter investors from other Member States from making such investments and, consequently, affect access to the market... ${ }^{137}$

In the case in question, the restrictions were attributable to the State. It might be said that, if the same provisions had been adopted by private shareholders, without the participation of the State, the relevant arrangements would not have deterred investors from making such investments, and would not have amounted to restrictions on capital movement. While this argument might be plausible as regards the powers of prior approval of the special shareholder of decisions to sell designated airports or wind up the company, it is not really plausible as regards the $15 \%$ equity limitation. The reason why that limitation deters investors is that it makes investment with a view to exercising a controlling influence over the company impossible. The fact that the limitation was introduced at the behest of the State and maintained by virtue of the existence of the special share held by the State cannot really detract from this fundamental point. It is difficult to avoid the conclusion that an equity limitation in a corporate constitution, introduced by private shareholders, and maintained by the existence of a special share in the hands of a private shareholder, could amount to a restriction on capital movement, and a restriction on freedom of establishment. While doubts have been ex-

137 Case C-98/01 Commission v. United Kingdom [2003] ECR I-4641 para 47. 
pressed by the present writer about the horizontal effect of Article 56 EC, it has been argued that there are no grounds for entertaining the same doubts as regards Article 43 EC.

It has however also been argued that normal market behaviour on the part of one market operator cannot in itself amount to a restriction the fundamental freedom of another. Could our hypothetical equity limitation - imposed and maintained solely by private action - be defended on the ground that it comprises normal market behaviour? It is to be noted that such a limitation would neither enable shareholders, nor the company itself, to maintain or improve their position on the market; it would entrench the position of the board of the company, and deny access to the market in corporate control by preventing such a market from operating. On the face of it, such a limitation could not be regarded as normal market behaviour. It would seem to amount to a serious restriction on the right of establishment, and would require to be justified by a mandatory requirement in the general interest. In such circumstances it would be necessary to consider the rationale of the corporate structure. Suppose the company concerned published a newspaper and that the equity limitation backed by the special share had been established as part of a scheme to ensure editorial independence for the newspaper in question. ${ }^{138}$ Any restrictions on freedom of establishment might be justified by the public interest in press diversity. ${ }^{139}$

\section{Action taken by the board of a company to frustrate a takeover bid}

Similar arguments might apply to measures permitted by or adopted under a corporate constitution, which are intended to and do restrict access to the market in corporate control. Into this category might fall certain conduct of the kind referred to in Article 9(2) of Directive 2004/25/ $\mathrm{EC}$ on take-over bids, taken to frustrate a bid, without the consent of the general meeting, where a Member State has opted out of the latter provision. ${ }^{140}$ The following is a selective account of aspects of the Directive intended to provide context for the discussion of the possible horizontal effect of Article 43 EC. ${ }^{141}$ Article 9(2) of the take-over Directive provides:

\footnotetext{
138 The present writer is conscious of the loose parallel with the arrangements applicable to Reuters when it was floated in 1984.

139 Cf Case C-368/95 Familiapress [1997] ECR I-3689.

140 See, in general, Wyatt, Dashwood and others (n 91) 20-036, 20-037. See also Guus Kemperink and Jules Stuyck, 'The Thirteen Company Law Directive and Competing Bids, (2008) 45 CML Rev 115-119.

${ }^{141}$ For an excellent analysis of the history and terms of the Takeover Bid Directive, see Thomas Papadopoulos, 'The European Union Directive on Takeover Bids: Directive 2004/25/ EC' (2008) 6 (3) ICCLJ 13-102.
} 
During the period referred to in the second subparagraph [viz., while a bid is pending], the board of the offeree company shall obtain the prior authorisation of the general meeting of shareholders given for this purpose before taking any action, other than seeking alternative bids, which may result in the frustration of the bid and in particular before issuing any shares which may result in a lasting impediment to the offeror's acquiring control of the offeree company. ${ }^{142}$

The Commission's explanatory memorandum says of the draft text of the above:

Where control of the offeree company is at stake, it is important to ensure that its fate is decided by its shareholders. The authorisation of the general meeting must therefore be given explicitly with a view to responding to a specific bid....The Directive does not define the measures which can frustrate a bid. In general, such measures may be all operations which are not carried out in the normal course of the company's business or not in conformity with normal market practices. ${ }^{143}$

The effect of Article 9(2) is that, apart from seeking alternative bids, the board is precluded from adopting other 'defensive' measures (e.g., poison pills, sale of crown jewels etc. ${ }^{144}$ ) without the prior consent of the general meeting, if they may result in the frustration of the bid. But this and other provisions are subject to opt out and reciprocity provisions. ${ }^{145}$ The Directive allows Member States to opt out of the rules on defensive measures for companies registered in their territories. Companies registered in those Member States which have opted out must nevertheless be allowed to opt in if they wish. And Member States may authorise companies otherwise subject to Articles 9(2) not to apply that regime if they

${ }_{142}$ Art 9(3) makes the following provision for the general meeting which decides on any defensive measures: 'Restrictions on voting rights provided for in the articles of association of the offeree company shall not have effect at the general meeting of shareholders which decides on any defensive measures in accordance with Article 9.

Restrictions on voting rights provided for in contractual agreements between the offeree company and holders of its securities, or in contractual agreements between holders of the offeree company's securities entered into after the adoption of this Directive, shall not have effect at the general meeting of shareholders which decides on any defensive measures in accordance with Article 9.

Multiple-vote securities shall carry only one vote each at the general meeting of shareholders which decides on any defensive measures in accordance with Article 9.'

143 COM (2002) 534 final 8.

144 A 'poison pill' gives rights to existing shareholders if a hostile bidder takes control; the 'sale of crown jewels' involves selling valuable assets of the company. See, for example, Kirchner and Painter, 'Takeover Defenses under Delaware Law, the Proposed Thirteenth EU Directive and the New German Takeover Law: Comparison and Recommendations for Reform' (2002) 50 American Journal of Comparative Law 451, 452.

145 Art 12. 
are the subject of a takeover by a company which does not apply that regime. ${ }^{146}$ A possible legal argument against the opt out and reciprocity provisions of the Directive is that they authorise at least some defensive conduct by the board of an offeree company which would seem to amount to an infringement of the right of establishment of a bidding company.

The rationale of the takeover Directive, referring in its preamble first and foremost to Article 44(1) EC, which has as its aim freedom of establishment, is clearly to achieve freedom of establishment, and the assumption underlying Article 9(2) of the Directive, which prohibits conduct likely to frustrate a bid without the prior authority of the general meeting, seems to be that such defensive conduct, unless taken with the prior authorisation of the general meeting, constitutes an obstacle to the freedom of establishment. It is interesting that the Commission's commentary on the original proposal for 'undiluted' Article 9(2) regards defensive measures as not being "carried out in the normal course of the company's business' and not being 'in conformity with normal market practices'. This is consistent with the approach of the present writer to the effect that normal market behaviour cannot in principle amount to a restriction on the fundamental freedom of market operators, but that behaviour other than normal market behaviour can constitute such a restriction if, inter alia, it restricts access to the market.

The fact that Article 9(2) is drafted so as to cover all defensive conduct of the board likely to hinder exercise of the right of establishment does not necessarily mean that all conduct incompatible with the latter Article would also be incompatible with the right of establishment of a bidder. Article 9(2) is a preventative rule which protects the interests of bidder and shareholders by requiring the consent of the general meeting in all cases to action of the kind referred to. So if the general meeting of a company gives authority to the board, in advance of any bid being made, to adopt certain defensive measures to protect shareholders from inadequate offers, and on the basis that such defensive measures are likely to increase the ability of the target company to negotiate a higher premium, it will be inconsistent with Article 9(2) for the board to take such defensive measures.

Yet it is not at all clear that action taken by the board in such circumstances should be considered to amount to an infringement of Article $43 \mathrm{EC}$. It has been suggested that non discriminatory activities by or on behalf of market operators to improve their market position vis-à-vis their competitors or their suppliers or customers, are not in principle and in general to be regarded as restrictions on the fundamental freedoms of others, though discriminatory conduct on the part of market operators,

146 It is debateable whether reciprocity may only be invoked by companies which have opted into the art 9(2) regime, or all companies subject to that regime. The present writer adopts the latter view. But it is not really significant to the present discussion. 
or activities which restrict the access to the market of other market operators, would seem capable of amounting to such restrictions. If this analysis is correct, conduct of the kind described above; viz., defensive measures authorised in advance of a bid but with a view to protecting shareholders from inadequate bids, and increasing the premium for control, cannot be regarded as a restriction on the right of establishment.

On the other hand, Article $43 \mathrm{EC}$ would seem to impose some limits on the consequences of opting out of Article 9(2), as would Article 3(c) of the Directive, and the latter provision might be read as aiming in part to ensure that opting out of Article 9(2) remains compatible with Article 43 EC. Opting out of Article 9(2) does not suspend or create an exception to application of the general principle laid down in Article 3 (c) of the Directive, to the effect that 'the board of an offeree company must act in the interests of the company as a whole and must not deny the holders of securities the opportunity to decide on the merits of the bid' (emphasis added). Opting out of Article 9(2) would not seem to authorise defensive action by a board which frustrates a bid which is manifestly adequate and thereby deny shareholders the opportunity to decide on the merits of the bid. On this view, opting out of Article 9(2) authorises the board to take defensive action to protect shareholders from inadequate bid, but not to deprive shareholders of the right to take advantage of manifestly adequate bids. To read the authorisation to opt out of Article 9(2) otherwise would be incompatible with Article 3 (c); at any rate where a bidder is incorporated in a Member State and entitled to rely upon Article 43 EC. ${ }^{147}$ A bidder incorporated in a third country would not be entitled to rely upon Article 56 EC if the latter Article has solely vertical effect. Nor would such a bidder be entitled to rely upon the general principle of equality, if the argument advanced above to this effect is correct. In any event, in the case of a bidder incorporated in a third country Article 56 EC might be subject to exception pursuant to Article 57(1) EC. ${ }^{148}$

It follows that, in the view of the present writer, opting out of Article 9(2) will still leave certain conduct caught by the latter Article prohibited by the Directive, because such conduct would place the board in default of Article $43 \mathrm{EC}$ - at any rate, in the case of bids by companies incorporated in Member States. In principle, any defensive measure, other than seeking alternative bids, might fall within this category, if it has the consequence of frustrating a manifestly adequate bid. Conduct which amounts to a restriction on the right of establishment, however, may be justified by overriding reasons in the public interest, such as the protection of work-

147 Art 43 EC applies only to companies or firms formed in accordance with the law of a Member State and having their registered office, central administration or principal place of business within the Community. See art 48 EC.

148 See n 129. 
ers, subject to the principle of proportionality. It might be difficult in practice to demonstrate that the frustration of a bid to take over a company amounting to a proportionate measure to protect the employees of the company, or the jobs created by the activities of the company. ${ }^{149}$

\section{Conclusion}

The judgments in Viking and Laval confirm the Court's previous case law on the horizontal effect of Articles 39, 43 and $49 \mathrm{EC}$, and extend the horizontal effect of Articles 43 and 49 EC to cover collective action of trade unions by way of strikes, boycotts and the like. One effect of this is an extension of Community regulatory competence to cover this same subject matter, despite the contrary indications in Article 137(5) EC. The judgment in Viking implies that Article $28 \mathrm{EC}$ is also capable of horizontal effect, at least in cases where collective action of individuals produces regulatory effects similar to those resulting from State action. This development also implies corresponding Community competence to regulate such conduct. The Court's reasoning leaves room for future incremental increases in the horizontal effect of fundamental freedoms in cases which involve contractual rules, in particular rules regulating employed or self employed activities, or conduct authorised by such rules, or which simply involve the exercise by private bodies of their legal autonomy. The approach to horizontal effect in Viking, for example, supports the argument that provisions of a corporate constitution could amount to a restriction on freedom of establishment, as could certain action taken by the board of a company to frustrate a takeover bid. A related issue is the horizontal effect of the fundamental principle of equality, apparently endorsed in the Mangold case. Even a restrained reading of Mangold would suggest that the prohibition of discrimination on grounds of nationality in Article 12 EC might have horizontal effect in circumstances falling within the material scope of Community law, such as the supply of goods, services, and business accommodation. A similar conclusion could be reached as regards discrimination in the sale of goods, services and real property to non residents. In the view of the present writer, it would not be excessively burdensome in such circumstances to impose on private market operators the obligation not to depart from their normal terms and conditions of sale, in the case of non-nationals or non-residents, unless such departure represented normal market behaviour.

149 In Case C-112/05 Commission v Federal Republic of Germany [2007] ECR I-8995, the Court held that provisions of the 'Volkswagen Law' were liable to deter investors from other Member States from investing in the company's capital, and that this amounted to an infringement of art $56 \mathrm{EC}$. The Court rejected on proportionality grounds the arguments that the contested arrangements were necessary to protect workers' interests and to protect jobs created by the activities of Volkswagen. See paras 74 and 80 . 